\title{
The (Mis)Representation of African American Music: The Role of the Fiddle
}

\author{
JACQUELINE COGDELL DJEDJE
}

\begin{abstract}
During the early twentieth century, research on African American music focused primarily on spirituals and jazz. Investigations on the secular music of blacks living in rural areas were nonexistent except for the work of folklorists researching blues. Researchers and record companies avoided black fiddling because many viewed it not only as a relic of the past, but also a tradition identified with whites. In the second half of the twentieth century, rural-based musical traditions continued to be ignored because researchers tended to be music historians who relied almost exclusively on print or sound materials for analyses. Because rural black musicians who performed secular music rarely had an opportunity to record and few print data were available, sources were lacking. Thus, much of what we know about twentieth-century black secular music is based on styles created and performed by African Americans living in urban areas. And it is these styles that are often represented as the musical creations for all black people, in spite of the fact that other traditions were preferred and performed. This article explores how the (mis)representation of African American music has affected our understanding of black music generally and the development of black fiddling specifically.
\end{abstract}

Although music historians acknowledge a prominent African American fiddle tradition during the slave era in the United States, scholarly research on this topic has been limited. ${ }^{1}$ Yet, available evidence indicates that fiddling was pervasive for entertainment at family and other social gatherings in many African American communities between the seventeenth and nineteenth centuries, and the fiddle continued to be an important instrument in early-twentieth-century (i.e., pre-World

The National Endowment for the Humanities as well as the Academic Senate, the Institute of American Cultures, and the Ralph J. Bunche Center for African American Studies at the University of California, Los Angeles (UCLA) supported my research on this subject. Portions of the article were presented at the North Atlantic Fiddle Convention in St. Johns, Newfoundland, Canada, in August 2008, and the International Council for Traditional Music's 40th World Conference in Durban, South Africa, in July 2009. Special thanks go to Eddie S. Meadows, Sule Greg Wilson, and Scott Linford for reading and making suggestions on drafts of this article.

${ }^{1}$ Although tunings may vary, no differences exist physically or in terms of construction between the fiddle and the violin used by most musicians in the United States. However, many people in the United States associate the word "fiddle" with folk culture, the working class, and musicians who perform old-time, country, and bluegrass music, whereas "violin" tends to be identified with elite culture and musicians formally trained in European art music. In lectures and interviews, well-known jazz violinists also indicate that differences are primarily cultural; see John Blake, lecture demonstration on "Jazz and the Violin," Billy Taylor's Jazz at The Kennedy Center, with Billy Taylor and the Billy Taylor Trio, John F. Kennedy Center Performing Arts Series, Washington, D.C., 7 February 2001, http://www. npr.org/programs/btaylor/archive/blake.html; Karen Briggs, lecture demonstration on "Women in Jazz" in Ethnomu M109, University of California, Los Angeles, 11 March 2008; and Regina Carter, personal interview with the author, San Francisco, CA, 21 March 2011. Because this essay concerns black fiddling, the aforementioned cultural associations are used in this discussion, including in solo fiddle and group performances such as string bands that include fiddle. See also Charles Wolfe, The Devil's Box: Masters of Southern Fiddling (Nashville, TN: Country Music Foundation Press and Vanderbilt University Press, 1997). 
War II) blues and jazz bands. While only occasionally included in late-twentiethcentury African American jazz and popular music groups, the fiddle remained integral to some rural black performers of old-time, country, and zydeco music. Failure to examine the role of the fiddle in the performance of these genres has not only resulted in the misrepresentation of African American music, but it has also led to an incomplete view and understanding of musicking among blacks and whites. $^{2}$

Several reasons may account for the non-identification of the fiddle with black culture in the twentieth century. When scholarly research on African American music began during the nineteenth and early twentieth century, music researchers tended to focus on religious music, specifically spirituals, a sacred genre typically accompanied by body percussion. Since most people in the United States during the late 1800s and early 1900s associated fiddling with secular culture, and the fiddle, through the early twentieth century, was often called the devil's instrument, rarely was it used to accompany religious music. ${ }^{3}$

With the exception of works by scholars such as Howard Odum and Thomas W. Talley, early writings on late-nineteenth and early-twentieth-century black secular music focused primarily on blues and jazz because researchers considered these genres to be different, new, and dynamic. Because many folklorists (e.g., Stetson Kennedy of Florida, and John and Alan Lomax of the Library of Congress) believed blues had interesting lyrics that addressed issues and problems confronting blacks, and that the fiddle was a relic of the past identified primarily with whites, they avoided research on traditions in which black fiddlers were dominant. As a result, most folklorists did not begin collecting materials on rural black secular music until the 1930s. ${ }^{4}$

\footnotetext{
${ }^{2}$ Based on findings from his analysis of ex-slave narratives and runaway advertisements in U.S. eighteenth-century newspapers, English scholar Robert B. Winans, who is also known for his research on the banjo, argues that the fiddle was the prominent instrument used by the enslaved through the nineteenth century. See Winans, "Black Instrumental Music Traditions in the Ex-Slave Narratives," Black Music Research Journal 10, no. 1 ([Spring 1982] Spring 1990): 43-53; and Winans, "Black Musicians in Eighteenth-Century America: Evidence from Runaway Slave Advertisements," in Banjo Roots and Branches: New Explorations, ed. Robert B. Winans (Urbana: University of Illinois Press, forthcoming). The few publications that focus on black fiddling include Theresa Jenoure, "The AfroAmerican Fiddler," Contributions in Black Studies: A Journal of African and Afro-American Studies 5, no. 2 (1981): 68-81; Marshall Wyatt, liner notes to Violin, Sing the Blues for Me: African-American Fiddlers 1926-1949, Old Hat CD 1002, 1999; Wyatt, liner notes to Folks, He Sure Do Pull Some Bow, Old Hat CD 1003, 2001; and Paul F. Wells, "Fiddling as an Avenue of Black-White Musical Interchange," Black Music Research Journal 23, nos. 1-2 (Spring/Fall 2003): 135-47. Musicking, a term coined by Christopher Small, refers to all activity that affects or takes place during a musical performance; see Small, Musicking: The Meanings of Performing and Listening (Middletown, CT: Wesleyan University Press, 1998), 10.

${ }^{3}$ Although publications on spirituals date from the mid-nineteenth century, scholarly interest in gospel music on a large scale did not begin until the mid-twentieth century; see Irene V. Jackson, AfroAmerican Religious Music: A Bibliography and a Catalogue of Gospel Music (Westport, CT: Greenwood Press, 1979). For a discussion of reasons the fiddle is sometimes called the devil's instrument, see the introduction in Wolfe, The Devil's Box, xv-xxiv.

${ }^{4}$ Howard W. Odum, "Folk-Song and Folk-Poetry as Found in the Secular Songs of the Southern Negroes," Journal of American Folklore 24, no. 93 (July-September 1911): 255-94; and 24, no. 4 (October-December 1911): 351-96; Thomas Washington Talley, Negro Folk Rhymes (Wise and Otherwise) (New York: Macmillan, 1922); Dwight DeVane, personal interview with the author, Polk City,
} 
Even record companies of the twenties and thirties segregated music into separate series: one designed for blacks (blues, jazz, religious music, and vaudeville songs) and another for whites (fiddle, banjo, some religious music, and jazz performed by whites). Because the music of African American fiddlers did not fit neatly into either category, few black fiddlers made recordings. A handful of commercial recordings of black fiddling date to the 1920s, and an even smaller number of field recordings by black fiddlers was made beginning only in the early 1940 s. $^{5}$

In the second half of the twentieth century, black fiddling and other rural-based musical traditions continued to be ignored because most researchers tended to be music historians who relied almost exclusively on print or sound materials for analyses. ${ }^{6}$ Commenting on the importance of recordings in documenting the history of fiddling in the United States, folklore and music scholar Charles Wolfe writes, "Since these older recordings are often the starting point for modern researchers, a lack of recordings all too often meant a lack of research, and a lack of knowledge."7 Because rural black fiddlers who performed secular music rarely had an opportunity to record and few print data were available on them, much of what we know about black secular music in the twentieth century is based more (or primarily) on how the media and researchers represented African American music than on what was actually created and performed by African Americans. ${ }^{8}$

\section{Representation}

Because representation is an important issue in this essay and to explain my use of the concept, we should review its meaning. Most dictionaries include several definitions for "represent." Yet, the descriptions most relevant for this discussion are:

FL, 10 August 1987; Elijah Wald, Escaping the Delta: Robert Johnson and the Invention of the Blues (New York: HarperCollins, 2004), 72; Karl Hagstrom Miller, Segregating Sound: Inventing Folk and Pop Music in the Age of Jim Crow (Durham, NC: Duke University Press, 2010), 1-13.

${ }^{5}$ Bruce Bastin, Red River Blues: The Blues Tradition in the Southeast (Urbana: University of Illinois Press, 1986); Charles Wolfe, "Black String Bands: A Few Notes on a Lost Cause," The Old-Time Herald: A Magazine Dedicated to Old-Time Music 1, no. 1 (Fall 1987): 15-18; Robert M. W. Dixon, John Godrich, and Howard W. Rye, Blues and Gospel Records: 1890-1943, 4th ed. (New York: Oxford University Press, 1997); Altamont: Black Stringband Music from the Library of Congress, Rounder 0238, 1989; Wald, Escaping the Delta, 43-69; John W. Work, Lewis Wade Jones, Samuel C. Adams Jr., Robert Gordon, and Bruce Nemerov, eds., Lost Delta Found: Rediscovering the Fisk University-Library of Congress Coahoma County Study, 1941-1942 (Nashville, TN: Vanderbilt University Press, 2005); and John W. Work III, Recording Black Culture, Spring Fed Records SFR 104, 2007.

${ }^{6}$ Eileen Southern, a musicologist, and Dena J. Epstein, a music librarian, are two of the most noted scholars of the late twentieth century to publish on the history of African American music. Due to their pioneering efforts, research on black music increased immensely because they identified sources and data that could be used as a basis for further investigations. See Eileen Southern, The Music of Black Americans: A History (New York: W. W. Norton, 1971, 1983, 1997); and Dena J. Epstein, Sinful Tunes and Spirituals: Black Folk Music to the Civil War (Urbana: University of Illinois Press, 1977).

${ }^{7}$ Charles Wolfe, review of With Fiddle and Well-Rosined Bow: Old-Time Fiddling in Alabama by Joyce Cauthen (Tuscaloosa: University of Alabama Press, 1989), Devil's Box 23, no. 2 (Summer 1989): 48.

${ }^{8}$ Pete Lowry, "Atlanta Black Sound: A Survey of Black Music from Atlanta During the Twentieth Century," The Atlanta Historical Society Bulletin 21, no. 2 (Summer 1977): 92-93. 
(1) Represent: to serve as a sign or symbol of; to portray or exhibit in art-depict; to serve as the counterpart or image of-typify.

(2) Misrepresent: to give a false or misleading representation of, usually with an intent to deceive or be unfair. ${ }^{9}$

In explaining the importance of representation to cultural meaning, cultural theorist Stuart Hall writes, "The emphasis on cultural practices is important. It is participants in a culture who give meaning to people, objects and events. ... In part, we give things meanings by how we represent them - the words we use about them, the stories we tell about them, the images of them we produce, the emotions we associate with them, the ways we classify and conceptualize them, the values we place on them." ${ }^{10}$ Later in his discussion, Hall raises several questions that are pertinent to understanding representation: "Do things-objects, people, events in the world-carry their own, one, true meaning? Or are meanings constantly shifting as we move from one culture . . . to another? Is it through our systems of representation ... that meaning is fixed?" 11 Hall also believes that two systems of representation exist: mental and language. "First, there is the 'system' by which all sorts of objects, people and events are correlated with a set of concepts or mental representations which we carry around in our heads. ... We must also be able to represent or exchange meanings and concepts, and we can only do that when we also have access to a shared language. Language is therefore the second system of representation involved in the overall process of constructing meaning." 12

As an object in global culture, the fiddle (or bowed lute) has diverse cultural meanings. Among Arab Bedouins, the bowed lute (called rabab or rebab) continues to be regarded as a folk instrument to accompany poetry and legends. "Among the Chinese, bowed chordophones were at first folk instruments" before their adoption in a different form (e.g., the two-stringed Chinese erhu) as court instruments. ${ }^{13}$ In early Europe, street and court musicians often played the rebec, which is derived from the Arab rabab, before it developed into what we now know as the violin. Cultural meanings for the bowed lute are also diverse among societies in West Africa. Whereas some Hausa people in northern Nigeria use the goge (the Hausa term for the fiddle) to call the spirits in religious worship, the Dagbamba of Ghana and Fulbe of Senegambia regard the gondze and nyanyeru as a symbol of political authority and ethnic identity, respectively (see Figures 1, 2, and 3). ${ }^{14}$

${ }^{9}$ Both definitions can be found in Webster's New Collegiate Dictionary (Springfield, MA: Merriam, 1974), 982 and 736, respectively.

${ }^{10}$ Stuart Hall, "Introduction," in Representation: Cultural Representations and Signifying Practices, ed. Stuart Hall (London: Open University/Sage, 1997), 3.

${ }^{11}$ Hall, "Introduction," 7

${ }^{12}$ Hall, "Representation, Meaning and Language," in Representation, 17-18.

${ }^{13}$ Sibyl Marcuse, Musical Instruments: A Comprehensive Dictionary (New York: W. W. Norton, 1975), 65.

${ }^{14}$ Sibyl Marcuse, Musical Instruments; Jacqueline Cogdell DjeDje, Fiddling in West Africa (1950s1990s): The CD Recording, UCLA Ethnomusicology Publications, 2007; Jacqueline Cogdell DjeDje, Fiddling in West Africa: Touching the Spirit in Fulbe, Hausa, and Dagbamba Cultures (Bloomington: Indiana University Press, 2008). 


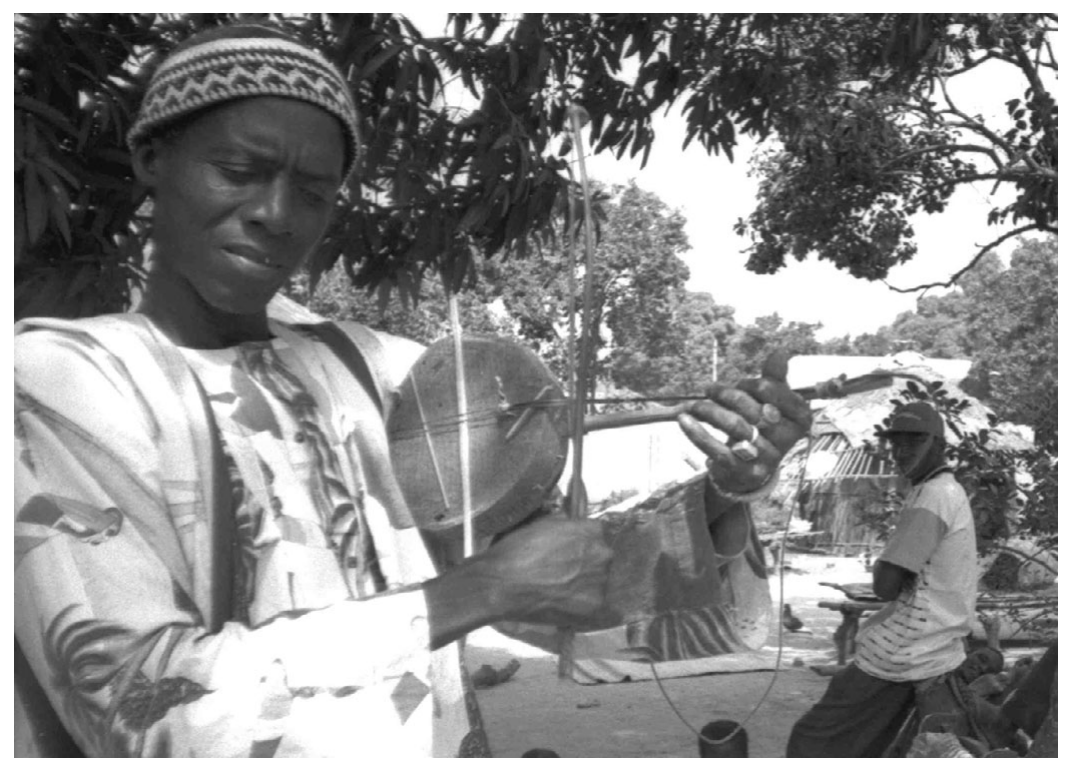

Figure 1. Tamba Kandeh of The Gambia playing the Fulbe nyanyeru. Photo by Jacqueline Cogdell DjeDje, December 1994.

In the United States, the fiddle has been depicted historically as a symbol of European and Anglo culture. When African Americans have been identified with the fiddle (Figure 4), ${ }^{15}$ often it is in the context of emulating or imitating Europeans. These beliefs and attitudes regarding the fiddle resonate in the cultural memory of peoples living in the United States because of the stories they have been told by researchers and those who control the media (see discussion below). Rarely are these conceptualizations or stereotypes questioned because through "systems of representation" the meanings have become fixed. ${ }^{16}$

Because we give objects (i.e., musical instruments) meaning by the words, stories, images, emotions, and values we associate with them, the fiddle in the United States serves as an example of misrepresentation. Neglecting to acknowledge fiddling as a tradition identified with blackness, but primarily a product of whiteness, has led to

${ }^{15}$ Joe Thompson (1918-2012), one of the few African Americans fiddlers of his generation to continue performing old time music through the early twenty-first century, began fiddling as a youngster with family members during the first half of the twentieth century and became nationally known for his contributions during the late twentieth and early twenty-first centuries; Joe Thompson, personal interview with the author, Mebane, NC, 21 August 1987. Fiddling by Thompson can be found on several recordings, including Ain't Gonna Rain No More: Blues and Pre-Blues from Piedmont North Carolina, Rounder 2016, 1978; Eight-Hand Sets and Holy Steps: Early Dance Tunes and Songs of Praise from North Carolina's Black Tradition, Longleaf Records LL001RE, [1978] 1989; Black Banjo Songsters of North Carolina and Virginia, Smithsonian Folkways CD 40079, 1998; Joe Thompson: Family Tradition, Rounder CD 2161, 1999; and Carolina Chocolate Drops and Joe Thompson, Music Maker Recordings-Lucky Guitar Music MMCD 101, 2008.

${ }^{16}$ Cecelia Conway, African Banjo Echoes in Appalachia: A Study in Folk Tradition (Knoxville: University of Tennessee Press, 1995), 73-75; Sule Greg Wilson, review of African Banjo Echoes in Appalachia: A Study in Folk Tradition by Cecelia Conway in Banjo Newsletter 23, no. 1 (August 1996): $7-10$. 


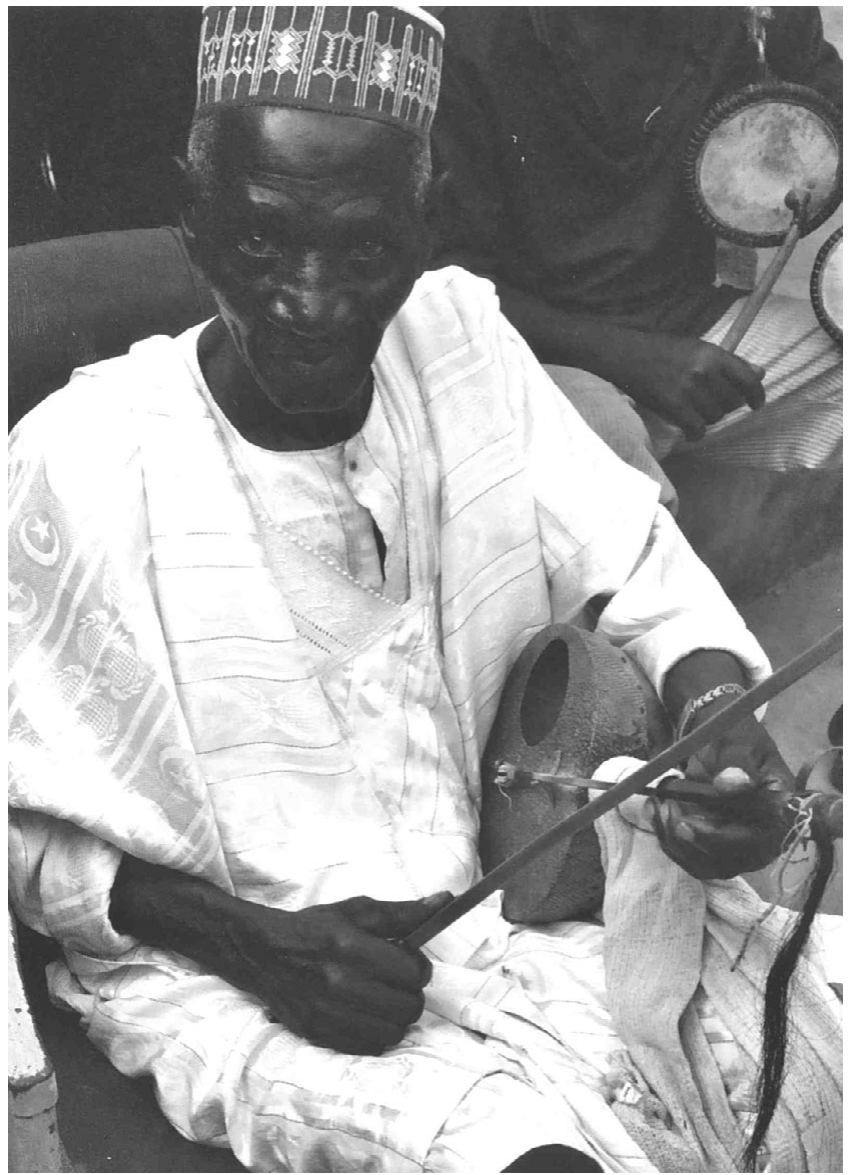

Figure 2. Musa dan Gado Saminaka of Nigeria playing the Hausa goge. Photo by Jacqueline Cogdell DjeDje, July 2003.

dramatic consequences. Misrepresentation has not only skewed our understanding of African American music, but it has also had an impact on the history and development of black music. In the discussion below, we will examine the consequences of misrepresentation and explore to what extent misleading representation was done "with an intent to deceive or be unfair." 17

Although misrepresentation has resulted in many stereotypes and misconceptions that have materialized during the development of African American music, this essay is concerned with two periods in U.S. history: (1) the seventeenth to nineteenth centuries, with special focus on connections with West Africa, slavery, and minstrelsy; ${ }^{18}$ and (2) the early twentieth century (1900s-30s), with attention given to migration, urbanism, and the media. I have chosen these periods not only because they are eras when black fiddling was most prominent, but also because

${ }^{17}$ Webster's, 736.

${ }^{18}$ Although minstrelsy has contributed significantly to negative stereotypes associated with blacks, the discussion in this article is limited to the performance tradition's impact on black fiddling. 


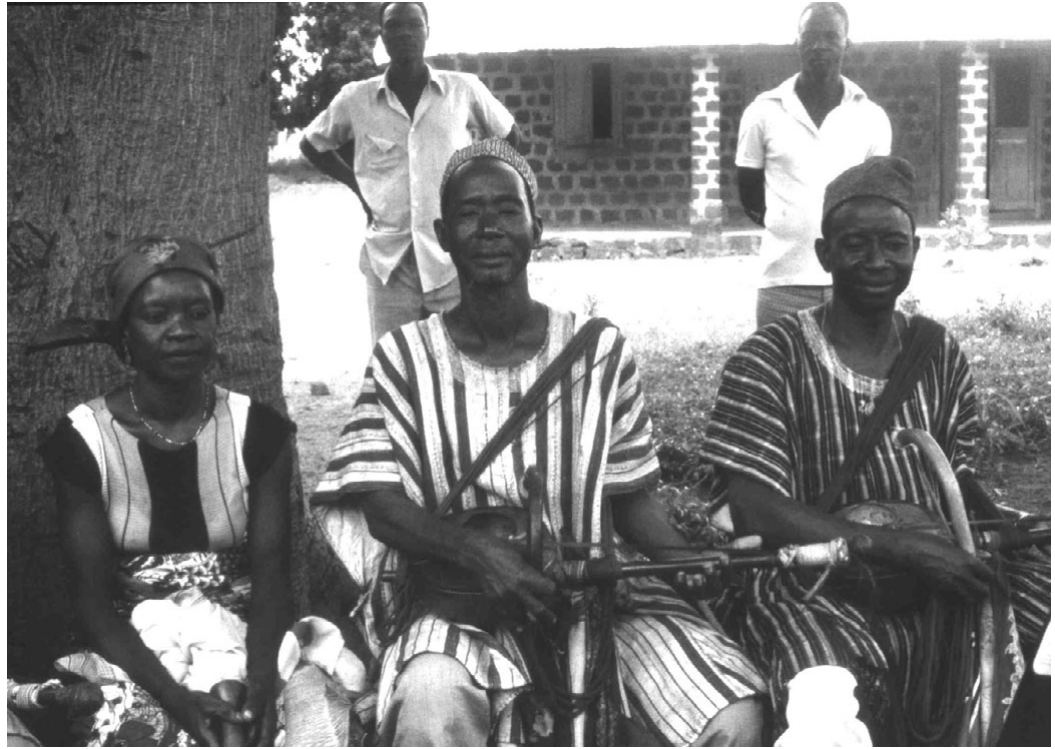

Figure 3. Salisu Mahama (center) of Ghana playing the Dagbamba gondze with his son, also on gondze, and his niece holding the gagle rattle. Photo by Jacqueline Cogdell DjeDje, August 1990.

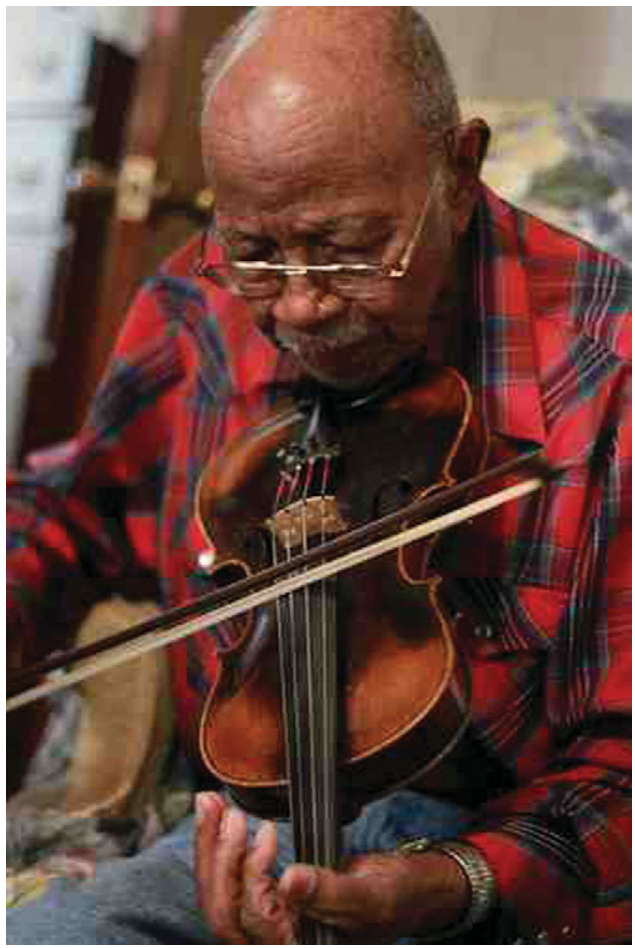

Figure 4. (Color online) Joe Thompson, African American fiddler from North Carolina. Photo by Larry Vellani, date unknown. Used by permission of Iris Chapman. 
they are moments when there tends to be general agreement among researchers about black music's history and development. ${ }^{19}$ Therefore, several questions or issues will be addressed for both time periods:

a. Why did we identify the fiddle primarily with Europeans and not with Africans or African Americans? The "we" in this question varies; it can mean researchers, the media, or peoples living in the United States.

b. What are the repercussions? How have our actions affected both the development and our understanding of black music in general and black fiddling?

\section{Seventeenth to Nineteenth Centuries: West African Connections, North}

\section{American Slavery, and Minstrelsy}

The fiddle or bowed lute in West Africa is dispersed primarily in the savannah or Sudanic region, from Senegal to Lake Chad, including the following countries: Mauritania, Senegal, The Gambia, Guinea-Bissau, Guinea, Mali, and parts of Burkina Faso, Ghana, Togo, Benin, Nigeria, Niger, Cameroon, and Chad (also see map in Figure 5). ${ }^{20}$ Not only is fiddling integral to many musical traditions in savannah West Africa, the use of bowed lutes in some areas dates to the eleventh or twelfth century. As a result of recent research, it has also become apparent that several enslaved groups from West Africa were transported to the Americas from areas in which fiddling was prominent. ${ }^{21}$

For example, historical research indicates that Africans transported to the Americas during the transatlantic slave trade were exported from eight principal regions: Senegambia (present-day Senegal and The Gambia); Sierra Leone (which extended along the coasts of present-day Guinea, Guinea-Bissau, and portions of Senegal and Sierra Leone); Windward Coast (mainly Liberia and present-day Côte d'Ivoire, but also portions of Sierra Leone); Gold Coast (roughly the same as present-day Ghana); Bight of Benin (present-day Togo, Benin, and Nigeria); Bight of Biafra (from the Niger-Delta in Nigeria to Cape Lopez in present-day Gabon); and Central and Southeast Africa (Gabon down to the Orange River in present-day Namibia as well as parts of Mozambique and Madagascar). ${ }^{22}$ "Culturally, these regions can be divided into three broad areas: (1) Western Sudan, which includes Senegambia and

\footnotetext{
${ }^{19}$ See Southern, Music of Black Americans, 1997; Epstein, Sinful Tunes and Spirituals, 1977.

${ }^{20}$ The ethnic groups listed on the map were identified from a variety of sources, including fieldwork in West Africa; commercial recordings; early writings by Arabs and Africans; journals and reports of European colonialists, explorers, and early travelers; and scholarly literature in ethnomusicology, music, history, folklore, anthropology, and other disciplines. Also, see DjeDje, "West Africa: An Introduction," in The Garland Encyclopedia of World Music, vol. 1, Africa, ed. Ruth M. Stone (New York: Garland, 1998), 442-70.

${ }^{21}$ DjeDje, Fiddling in West Africa (1950s-1990s): The CD Recording, DjeDje, Fiddling in West Africa: Touching the Spirit, DjeDje, Fiddling in West Africa (1950s-1990s): The Songbook (Los Angeles: UCLA Ethnomusicology Publications, 2008).

${ }^{22}$ Philip Curtin, The Atlantic Slave Trade: A Census (Madison: University of Wisconsin Press, 1969); David Eltis, "The Volume and Structure of the Transatlantic Slave Trade: A Reassessment," William and Mary Quarterly, 3rd. ser., no. 1 (January 2001): 17-46; Joseph E. Holloway, "The Origins of African American Culture," in Africanisms in American Culture, 2nd ed., ed. Joseph E. Holloway (Bloomington: Indiana University Press, 2005), 18-38.
} 


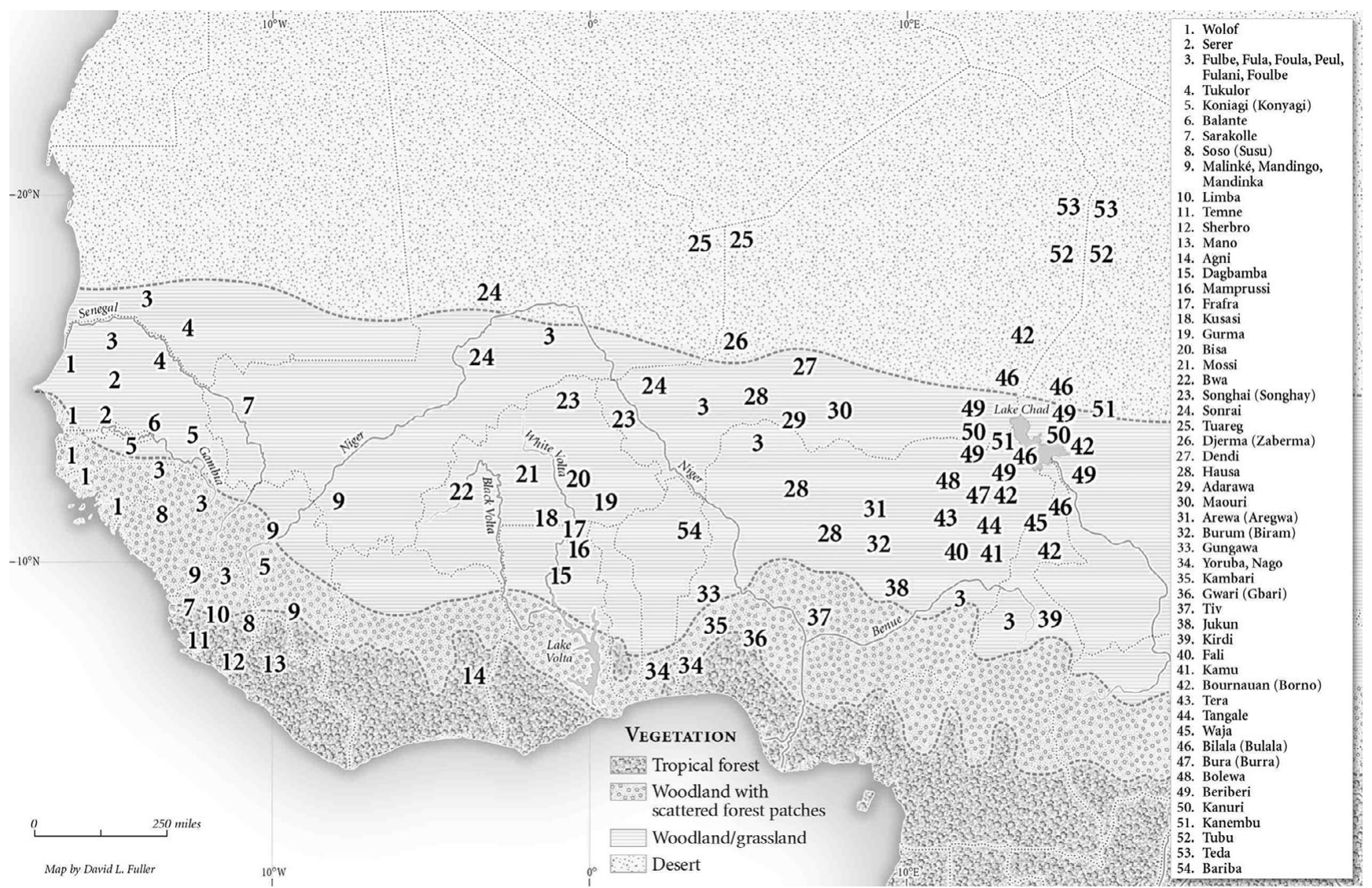

Figure 5. Distribution of people in West Africa who use the one-stringed fiddle. Map by David L. Fuller. Based on a map in Jacqueline Cogdell DjeDje, "Distribution of Ethnic Groups in West Africa Using the One String Fiddle," in Distribution of the One String Fiddle in West Africa (Los Angeles: UCLA Program in Ethnomusicology, Department of Music, 1980), 40-41; and in Fiddling in West Africa: Touching the Spirit (Bloomington: Indiana University Press, 2008), 24. 
portions of Sierra Leone; (2) West Africa, which can be divided into three subregions - the Bight of Biafra, the Bight of Benin and Gold Coast, the Windward Coast; and (3) Central and Southeast Africa." ${ }^{23}$ For this discussion, our focus is on the Western Sudan and West Africa.

Africans whose music cultural traditions included fiddling were exported from several locations: Senegambia and Sierra Leone (Fulbe, Serer, Susu, Temne, Tukulor, and Wolof); the Gold Coast (Dagbamba); and the Bights of Benin and Biafra (Bariba, Gbari, Gurma, Hausa, Nago, or Yoruba). Since these are peoples who had resided for hundreds of years in savannah and forest West Africa, their musical traditions (including fiddling) were firmly in place before the transatlantic slave trade began. Because earlier research on slave trading focused on groups living along the Atlantic Coast near ports of embarkation, much of the information about musicking in Africa also emphasized coastal traditions. Although many explanations can be given for researchers' interest in the music of groups living along the coast or forest West Africa, part of the reason has been the desire to identify linkages and/or retentions between Africans and blacks in the Americas. ${ }^{24}$ Unfortunately, the focus on coastal traditions has caused groups in the interior, the homeland of many enslaved Africans transported to the Americas, to be ignored, which has led to misconceptions about the music and culture of both Africa and African America. ${ }^{25}$

In fact, the place of exportation did not always reflect the ethnicity of those sold into slavery because Africans were often transported from various regions in the interior for trade on the Atlantic Coast. Commenting on how slave traders identified peoples for export, historian Darold D. Wax writes: "Confined to small enclaves of settlement dotting the coast, Europeans had to rely on the assistance and support of the natives, who alone were familiar with the hinterland and possessed of the knowledge that permitted them to make long journeys into the interior, perhaps as long as four or five hundred miles." ${ }^{26}$ Making a similar argument, historian Colin Palmer states: "The ports from which they embarked are not usually reliable indicators of the ethnicity of the captives, who often came from the interior and comprised many different peoples." 27 Paul Oliver's remarks in Savannah Syncopators are also noteworthy: "slaves were drawn not only from ... the Gold and Slave Coasts, Guinea and Calabar [in present-day Nigeria], but from deeper in the interior, and that these from the savannah regions, from Senegambia and among the Wolof and

${ }^{23}$ Jacqueline Cogdell DjeDje, "African American Music to 1900," in The Cambridge History of American Music, ed. David Nicholls (Cambridge: Cambridge University Press, 1998), 105-6.

${ }^{24}$ Composer and musicologist Olly W. Wilson argues that several features in West African music (e.g., emphasis on percussion and rhythm/polyrhythm) have influenced the music of African Americans. See Olly Wilson, "The Significance of the Relationship between Afro-American Music and West African Music,” The Black Perspective in Music 2, no. 1 (Spring 1974): 3-22.

${ }^{25}$ DjeDje, Fiddling in West Africa: Touching the Spirit, 60, 124, 184, 278, 289; Sylviane A. Diouf, Servants of Allah: African Muslims Enslaved in the Americas (New York: New York University Press, 1998).

${ }^{26}$ Darold D. Wax, "A People of Beastly Living': Europe, Africa and the Atlantic Slave Trade," Phylon: The Atlanta University Review of Race and Culture 41, no. 1 (1980): 19.

${ }^{27}$ Colin A. Palmer, "From Africa to the Americas: Ethnicity in Early Communities of the Americas,” Journal of World History 6, no. 2 (Fall 1995): 224-45. 
Mandingo peoples, formed a not inconsiderable number of them. Their culture may have been transplanted to the United States in many forms, including that of music." 28 Throughout West Africa, military conflicts between various groups produced war captives who were sold into slavery. For example, several wars took place in savannah West Africa during the period of the transatlantic slave trade. The Fulbe had conflicts with the Mande, Hausa, and rulers of Bornu at different points in time; the Asante also warred with different groups, including those in the northern regions of present-day Ghana. Therefore, just as people shipped from the Gold Coast may have included groups (e.g., the Dagbamba) that lived inland, the Bights of Benin and Biafra served as points of embarkation for people (e.g., the Gurma and the Hausa) who lived in or near the northern parts of presentday Benin and Nigeria. ${ }^{29}$

When discussing the impact of the transatlantic slave trade on the development of black music, few music scholars address the ethnicity and cultural traditions of Africans transported to the Americas. Instead, Africans are presented as a homogenous group with little differentiation. Interestingly, a similar approach is used when discussing Europeans and their interactions with Africans. Commenting on this issue, DjeDje writes, "the richness and diversity of all America's cultural traditions - African, European, African American, and Native Americanare overlooked, avoided, or skewed in a misguided effort to show commonalities, similarities and differences." Generalizations of this nature continue in present-day scholarship, which, in my opinion, accounts for much of the misrepresentation regarding the music making of ethnic and racial groups in the United States. ${ }^{30}$

In spite of the fiddle's association with African Americans, particularly during slavery, few researchers have focused on the instrument's connections with Africa. Because many scholars in earlier years considered fiddling in North America to be a European American tradition, most assumed that African Americans' use of the fiddle during slavery was due entirely to European influence. In the first and second editions of her classic work, The Music of Black Americans: A History, Eileen Southern attributes the popularity of fiddling among blacks to whites. ${ }^{31}$ Even in the third and final edition, she writes: "the references to slave musicians point out that most often they were violinists and flutists, a phenomenon perhaps to be attributed more to the demands of the white colonists for dance musicians than to mere coincidence or to any preference for these instruments among the black people." ${ }^{\prime 2}$ Probably because more information has become available about

${ }^{28}$ Paul Oliver, Savannah Syncopators: African Retentions in the Blues (New York: Stein and Day, 1970), 76.

${ }^{29}$ Curtin, Atlantic Slave Trade, 186-87, 245; Paul Oliver, The Story of the Blues (Middlesex, England: Penguin Books, [1969)] 1972); Akosua Adoma Perbi, A History of Indigenous Slavery in Ghana from the 15th to the 19th Century (Legon-Accra, Ghana: Sub-Saharan Publishers, 2004); Philip de Barros, "How Far Inland Did the Arm of the Slave Trade Reach? An Overview of the Slave Trade in Togo," Excavating the Past: Archaeological Perspectives on Black Atlantic Regional Networks Conference in Honor of UCLA Emeritus Professor Merrick Posnansky, 3-4 April 2009), unpublished manuscript, 27. http://www2.palomar.edu/users/pdebarros/TOGO\%20PAPER\%20with\%20MAPS\%20(5).pdf.

${ }^{30}$ DjeDje, "African American Music to 1900," 104.

${ }^{31}$ Southern, Music of Black Americans, 1971, 45; Music of Black Americans, 1983, 47.

${ }^{32}$ Southern, Music of Black Americans, 1997, 46. 
the subject matter in recent years, Robert B. Winans not only acknowledges the existence of bowed string instruments in Africa, he also suggests that both blacks and whites probably enjoyed fiddle music in the Americas during the slave era: "the vast majority of eighteenth-century black musicians played the fiddle, which was also the central instrument of the prevailing Anglo-American tradition that surrounded these blacks, although of course bowed instruments similar to fiddles were also known in regions of Africa from which the forebears of these slaves originally came. ... The advertisements do not provide any information on what music they played, but Anglo fiddling and dance repertory would likely have been at least a part of their repertory, along with specifically African American material." ${ }^{33}$

Recently, researchers investigating the history of the banjo in the United States have begun exploring West Africa, especially Senegambia and other parts of the region, for evidence of influences and linkages. ${ }^{34}$ Unlike drumming cultures in forest West Africa, in which emphasis is placed on layers of sound produced by percussive instruments (drums, bells, and rattles), the savannah includes sounds that fuse both melodic- and rhythmic-based instruments, with greater emphasis given to melody and melodic ornamentation. Because West African fiddling consisted of performances of the fiddle as a solo instrument, accompanied by percussion (rattle and drums), or in ensembles with drums, wind, and occasionally other string instruments, it is not far-fetched for enslaved Africans to have replicated these performance traditions in the Americas. ${ }^{35}$

In view of the fact that instruments in general have multiple identities that shift due to usage or circumstance, the fiddle has had several cultural meanings

${ }^{33}$ Winans, "Black Musicians in Eighteenth-Century America."

${ }^{34}$ As a result of works by Oliver and Epstein-for example, Oliver, Savannah Syncopators; Epstein, “The Folk Banjo: A Documentary History," Ethnomusicology 19, no.3 (September 1975): 347-71; and Epstein, Sinful Tunes and Spirituals - research on the history of the banjo in the United States has stimulated much discussion. Select publications on this topic include Winans, "Black Banjo Tradition in Virginia and West Virginia," Folklore and Folklife in Virginia: Journal of the Virginia Folklore Society 1 (1979): 7-30; Cecelia Conway, African Banjo Echoes in Appalachia; Sule Greg Wilson, review of African Banjo Echoes in Appalachia; Ulf Jägfors, "The African Akonting and the Origin of the Banjo," The Old-Time Herald: A Magazine Dedicated to Old-Time Music 9, no. 2 (Winter 2003-4): 26-33; Tony Thomas, "Why Black Banjo? The Black Banjo List Serve and the Black Banjo Gathering," The Old-Time Herald: A Magazine Dedicated to Old-Time Music 9, no. 7 (Spring 2005): 44-45; Peter Szego, "Searching for the Roots of the Banjo-Part I," The Old-Time Herald: A Magazine Dedicated to Old-Time Music 10, no. 4 (April-May 2006): 14-23; “Part II," 10, no. 5 (June-July 2006): 10-20; Greg Adams and Shlomo Pestcoe, "The Jola Akonting: Reconnecting the Banjo to its West African Roots," Sing Out! 51, no. 1 (2007): 43-51; Greg C. Adams and Paul Sedgwick, "Encountering the Akonting: A Cultural Exchange," The Old-Time Herald: A Magazine Dedicated to Old-Time Music 10, no. 9 (February-March 2007): 36-41; Greg C. Adams, "Nineteenth-Century Banjos in the Twenty-First Century: Custom and Tradition in a Modern Early Banjo Revival,” M.A. thesis, University of Maryland, College Park, 2012; and Shlomo Pestcoe and Greg Adams, "Banjo Roots Research: Changing Perspectives on the Banjo's African American Origins and West African Heritage," in Banjo Roots and Branches: New Explorations, ed. Robert Winans (Urbana: University of Illinois Press, forthcoming).

${ }^{35}$ In West Africa, combining the fiddle or bowed lute with percussion (rattles, drums, etc.) occurs more often than performing it with another string instrument such as a plucked lute. Among most peoples in West Africa, bowed and plucked lutes tend to be separate traditions with distinct histories and performance practices. See DjeDje, Fiddling in West Africa (1950s-1990s): The CD Recording; DjeDje, Fiddling in West Africa: Touching the Spirit; and DjeDje, Fiddling in West Africa (1950s-1990s): The Songbook. 
both in Africa and the Americas. ${ }^{36}$ Thus, fiddling among enslaved Africans actually reflects both resilience and acculturation. Blacks did not merely adopt the European fiddle because whites preferred it. Rather, the popularity of the fiddle among white Americans allowed some Africans the opportunity to maintain and signify on a tradition that was an important part of their culture prior to contact with Europeans. John Storm Roberts states, "the enthusiasm with which New World blacks took to the fiddle, not only in Brazil but in the United States and Cuba as well, is surely related to the occurrence of fiddle-type instruments in parts of Africa." ${ }^{37}$

In addition, the manner in which blacks performed on fiddle, combined with ensembles that included percussive instruments, reflects an African aesthetic that did not diminish as a result of contact with European culture. In describing the playing technique or musical sound produced by black fiddlers, critics and writers from the eighteenth through the twentieth centuries often used words such as "rough," "scraping," "sawing," and "jerky," which was distinct from "smooth," "clear" or "notey" to describe fiddling identified with whites. Caroline Howard Gilman's description of black musicking—-"sawing violins, harsh clarinets, jingling tambarines, crashing triangles, with the occasional climax of a base drum, make up in quantity what is deficient in quality" —on a nineteenth-century South Carolina slave plantation, and R. P. Christeson's comments about the rough, vigorous playing style of Bill Driver (1881-1985), a black Missouri fiddler popular during the early twentieth century, both suggest a preference on the part of African Americans for features common in Africa. Therefore, playing the fiddle in the Americas can be regarded as a reinforcement rather than a diminishment of Africanisms, which led to transformation and the development of new stylistic trends. ${ }^{38}$ In other words, acculturation did not necessarily mean a loss of tradition; rather, it allowed blacks greater flexibility, versatility, and opportunity to be creative in using ideas and material available to them, whether they were derived from African, European, or Native American cultures. ${ }^{39}$

${ }^{36}$ DjeDje, Fiddling in West Africa: Touching the Spirit, 7-8; Howard Marshall, Vivian Williams, and Phil Williams, Now That's a Good Tune: Masters of Traditional Missouri Fiddling (Seattle, WA: Voyager Recordings and Publications, 2008), 23-32; Dale Smith, "Missouri's Finest Fiddlers: Howard Marshall Traces Missouri's Fiddling History," Mizzou: The Magazine of Mizzou Alumni Association, University of Missouri (Summer 2009).

${ }^{37}$ John Storm Roberts, Black Music of Two Worlds: African, Caribbean, Latin, and African-American Traditions, 2nd ed. (New York: Schirmer Books, [1972] 1998), 75.

${ }^{38}$ Caroline Howard Gilman, Recollections of a Southern Matron (New York: Harper and Brothers, 1838), 76-77; R. P. Christeson, Old Time Fiddler's Repertory. Historic Field Recordings of Forty-One Traditional Tunes (Columbia: University of Missouri Press, [1976] 2011); DjeDje, "African American Music to 1900," 114-15; John Harrod, personal interview with the author, Owenton, KY, 6 August 1987.

${ }^{39}$ Building on the research and analyses of earlier scholars, select publications that include discussion of what I refer to as the fusions of musical cultures in the Americas include Ernest D. Brown, "The African/African American Idiom in Music: Family Resemblances in Black Music," in African Musicology: Current Trends, Volume II, ed. Jacqueline Cogdell DjeDje (Los Angeles and Atlanta: UCLA International Studies and Overseas Program/The James S. Coleman African Studies Center and African Studies Association Press, 1992), 115-34; and Portia K. Maultsby, "The Translated African Cultural and Music Past," in African American Music: An Introduction, 2nd ed., ed. Mellonee V. Burnim and Portia K. Maultsby (New York: Routledge, 2015), 3-22. 
Although immensely popular within black and white communities, fiddling had many critics. In addition to some whites characterizing the activity as evil, sinful, and an act of resistance, many blacks and whites believed fiddling encouraged behavior that was "un-civilized" (i.e., African). Interestingly, the fiddle never reached the stage of being outlawed, like the drum, due to fear of uprisings. Because the fiddle was culturally important to European Americans, and they often used musicking as a means to control and increase the economic productivity of the enslaved, fiddling among African Americans continued unabated in spite of its association with the profane. $^{40}$

Minstrelsy, an entertainment form developed in the early nineteenth century by whites that popularized negative portrayals and stereotyped performances of African Americans, had a major impact on the development of black fiddling. As a European American invention in imitation of African American culture, whites included African or African-derived instruments in minstrel ensembles. The fact that the fiddle as performed by blacks became an important source of entertainment in minstrelsy confirms that, prior to the nineteenth century, the instrument was common in African American culture. ${ }^{41}$ After emancipation, minstrelsy became an important context for black musicking, for it was one of the few opportunities for black fiddlers and other artists to maintain a livelihood as professional musicians.

\section{a. Why did researchers identify the fiddle primarily with Europeans?}

Reconstructing the history of enslaved Africans in the Americas is both difficult and complicated, given the paucity of resources. ${ }^{42}$ In earlier studies, confusion may have occurred because historians, when discussing influences from Africa, initially emphasized the place of exportation (which they knew more about) and not the peoples who were exported (for which they knew little because of the difficulty in determining this information). Because details were lacking, misrepresentation may have been unintentional. In discussing the problem of identifying the ethnicity of slave communities in the Americas, some authorities still urge researchers to be cautious with data because "significant cultural mixing between members of different African nations, between Africans and African Americans, and between these groups and Native Americans occurred in every colony." 43

\footnotetext{
${ }^{40}$ Epstein, Sinful Tunes and Spirituals, 210.

${ }^{41}$ Just as the instrumentation used in minstrel shows normally included fiddle, banjo, bones, and tambourine, the most prominent instruments mentioned in the ex-slave narratives were fiddle, banjo, and percussion. See Winans, "Black Instrumental Music Traditions in the Ex-Slave Narratives," 44.

${ }^{42}$ Even with new data, the amount and type of information for many areas are still limited. For example, the editors of The Trans-Atlantic Slave Trade: A Database on CD-ROM indicate that they cannot provide new information about the "names of African individuals or groups." Eltis, "Volume and Structure," 17.

${ }^{43}$ Lorena S. Walsh, “The Transatlantic Slave Trade and Colonial Chesapeake Slavery,” Organization of American Historians Magazine of History 17, no. 3 (April 2003): 13. However, there is a strong likelihood that fiddling in West Africa contributed to the prominence of fiddling among blacks in the Americas because many enslaved Africans were exported from several regions where fiddling was prominent (i.e., the tradition was not limited to one or two ethnic groups); see map in Figure 5. Also see Harold Courlander, Negro Folk Music, U.S.A. (New York: Columbia University Press, 1963); Oliver, Savannah Syncopators; Roberts, Black Music of Two Worlds.
} 
Yet, when some researchers emphasize the performance of drums and other percussive instruments in Africa to the exclusion of other musical traditions, the misrepresentation is intentional, not only to mark musical differences between various ethnic groups in the Americas, but also to perpetuate longstanding meanings and practices in the cultural memory of both African and European Americans. Therefore, associating blacks with drumming (an activity banned in the Americas because it had been used to incite revolt) also coincided with perceptions of Africa and Africans as threatening, cruel, and barbarous, which was distinct from the representation of Europe and Europeans, who performed melodic instruments (strings), as genteel, reserved, and respectable. ${ }^{44}$

b. What are the repercussions?

Serious misunderstandings now exist regarding the contributions and musical influences from both Africa and Europe in the development of music in the United States. The belief that Africa contributed rhythm and Europe melody to what became known as "American" fiddle music is too nice and neat because there are many musical traditions in Africa that can be described as melodic just as European culture is not completely devoid of musicking that emphasizes rhythm. ${ }^{45}$ As Olly Wilson explains, "careful examination reveals that it represents a gross over-simplification. ... [T] his position ignores the fact that it is the combination of many interrelated parameters that defines the Africanness of a musical practice, not the presence of absence of a single one." 46

In fact, different interpretations of existing material on European music suggest that alternative explanations need to be explored. For example, in discussing features that affected the music used in blackface minstrelsy, ${ }^{47}$ ethnomusicologist Christopher Goertzen comments on the use of syncopation in playing the banjo: "Although this drone is played off the beat, producing syncopation, a feature that is generally and justly taken to reflect African influence, that a drone is present at all points less to any sub-Saharan African musical tradition than to the Scottish bagpipes and various northern European types of dulcimer." ${ }^{8}$ Goertzen's point

${ }^{44}$ Epstein, Sinful Tunes and Spirituals, 39, 59-60; Southern, Music of Black Americans, 1997, 24, 101, 172, 251; Mark M. Smith, "Remembering Mary, Shaping Revolt: Reconsidering the Stono Rebellion," Journal of Southern History 67, no. 3 (August 2001): 513; Tanya Y. Price, "Rhythms of Culture: Djembe and African Memory in African-American Cultural Traditions," Black Music Research Journal 33, no. 2 (Fall 2013): 236.

${ }^{45}$ Sule Wilson, review of African Banjo Echoes in Appalachia.

${ }^{46}$ Olly Wilson, "The Significance of the Relationship Between Afro-American Music and West African Music,” 16.

${ }^{47}$ After slavery, blacks also supported and participated in minstrel shows. In fact, variations on minstrelsy in film, television, and other media continue to be popular in present day; see Yuval Taylor and Jake Austen, Darkest America: Black Minstrelsy from Slavery to Hip-Hop (New York: W. W. Norton, 2012).

${ }^{48}$ Christopher Goertzen, "English and Scottish Music," in The Garland Encyclopedia of World Music, vol. 3, The United States and Canada, ed. Ellen Koskoff (New York: Garland, 2001), 838. Concerning this point, Scott Linford, who is conducting research on music of the Jola in Senegambia and performs on the Jola plucked lute (ekonting), states: "While a European origin for the use of drone notes is certainly plausible, there is also strong evidence of the use of the shortest, highest-pitched string as a rhythmic drone by many ekonting players, providing a direct analogue [to the banjo] on 
about syncopation and its relationship to drone raises several issues. On one hand, it is noteworthy in that he presents a different interpretation for the use of rhythmic practices in minstrelsy by suggesting Europe, not Africa, as a source. On the other hand, using one element or feature to justify the cultural history or roots of a musical tradition is an example of an approach that we should avoid. Thus the larger issue is the manner in which we discuss the contributions of various music cultures to the development of "American" music. Identifying specific elements or traits can lead to misrepresentation because different characteristics, when examined in isolation, can be found in many cultures.

In the end, more investigation needs to be done on the history and development of music in colonial America to clarify what was contributed and/or maintained by peoples from Africa, Europe, and Native America. Because similar performance practices may have existed prior to contact, some may question whether identifying the origin of specific traits is useful. Nevertheless, as new information becomes available, our analysis and understanding of the histories of specific instruments and musical traditions need to occur to avoid misrepresentation based on outmoded assumptions and stereotypes.

On many levels, minstrelsy has played a significant but complicated role in the history of black fiddling. (1) The prominence of fiddling among minstrel performers provides evidence of the fiddle's association with black culture in the eighteenth century and possibly earlier. (2) Minstrelsy's popularity contributed to the development and growth of fiddling, especially in terms of repertoire and ensemble organization. Songs composed by white and black minstrel performers became favorites among both races. Although the fiddle/banjo ensemble (a combination that allowed the enslaved to fuse two instrumental traditions from the African continent in an innovative manner) started among African Americans during the eighteenth century, most likely it was the minstrel show that popularized the performance tradition during the nineteenth century. ${ }^{49}$ As Winans explains, "Traditional American banjo/fiddle music is as much an Afro-American tradition as an Anglo-American one." ${ }^{50}$ (3) Because of the emphasis it placed on difference, minstrelsy is one of the primary reasons for the misrepresentation and negative stereotypes associated with blacks in the United States. ${ }^{51}$ Commenting on this issue, ethnomusicologist Ronald Radano writes: “That northern white working-class performers were principally responsible for the latter invention [i.e., blackface minstrelsy] suggests an effort on their part to celebrate blackness in order to distance it (and an emerging African American working class) from their own racial status. As both David Roediger and Eric Lott have suggested, blackface performance played a key formative role in the

a West African plucked lute," Scott Linford, personal email communication to the author, 27 April 2015.

${ }^{49}$ David Evans, liner notes to Let's Get Loose: Folk and Popular Blues Styles from the Beginnings to the Early 1940s, New World Records NW 290, 1978.

${ }^{50}$ Winans, "Black Banjo Tradition in Virginia and West Virginia," 27; Tony Russell, Blacks, Whites and Blues (New York: Stein and Day Publishers, 1970), 26-27.

${ }^{51}$ In fact, variations on minstrelsy in film, television, and other media continue to be popular today; see Yuval Taylor and Jake Austen, Darkest America: Black Minstrelsy from Slavery to Hip-Hop (New York: W. W. Norton, 2012). 
evolution of whiteness as a racial category."52 (4) Because of its negative portrayal and misrepresentation of black culture, African Americans' rejection of minstrelsy contributed to the decline of black fiddling (see discussion below).

\section{Early Twentieth Century: Migration, Urbanism, and the Media}

Although several factors affected the misrepresentation of the fiddle in African American music during the first half of the twentieth century, in this discussion I focus on migration, urbanism, and the media because of the dramatic changes that resulted from their impact on the black culture. The first few decades of the twentieth century in the United States witnessed major shifts in the location and living patterns of blacks. During the First Great Migration (1915 to 1940), roughly 1.6 million blacks left their homes in the South to escape racism and find employment and a better education in the North. During the Second Migration (1940 to 1970), more than five million blacks relocated to urban areas for the same reasons many had moved in earlier years. Yet the likelihood of obtaining jobs in the defense industry was an additional motivating factor. Whereas Texas, Louisiana, and other states in the south-central region of the United States accounted for large numbers of black migrants to the Midwest and West, blacks in the other fourteen states of the South-especially Georgia, the Carolinas, Alabama, Louisiana, and Mississippi-moved to the Northeast as well as the Midwest. ${ }^{53}$

When black migrants settled in cities, most wanted to forget reminders and associations from the South, especially vestiges of slavery and the racism that emerged to replace it. Behavior that hinted of southern ways (e.g., dress, religious practices, and language) was regarded as backward and country. With the shift from a rural to an urban-based lifestyle, changes also occurred in the types of music performed, the contexts and occasions for performances, and the manner in which musicians expressed themselves. Not only did new genres such as jazz and gospel come into existence, but musicians also changed the old genres to fit new lifestyles. In urban areas, for example, country blues became vaudeville (i.e., classic) blues, city blues, urban blues, jump blues, and rhythm and blues. The string, brass, and jug band ensembles of rural areas became jazz ensembles in urban areas. Instrumentalists also responded to new developments in different ways. Whereas some continued to use the same resources in new contexts (playing the fiddle in jazz ensembles), others discarded the old and developed a totally new sound (replacing the fiddle with the clarinet in jazz ensembles). ${ }^{54}$

\footnotetext{
${ }^{52}$ Ronald Radano, "Race, Ethnicity, and Nationhood," in The Garland Encyclopedia of World Music, vol. 3, The United States and Canada, ed. Ellen Koskoff (New York: Garland, 2001), 67.

${ }^{53}$ Much of my discussion about the migration and urbanization of blacks is based on John Hope Franklin, From Slavery to Freedom: A History of Negro Americans, 5th ed. (New York: Alfred A. Knopf, [1947] 1980).

${ }^{54}$ Wyatt, liner notes to Folks, He Sure Do Pull Some Bow. For a discussion of northern-southern fusions, or what Guthrie Ramsey calls the "code-fusion aesthetic," in post-World War II blues and gospel music, see Guthrie P. Ramsey, Jr., Race Music: Black Cultures from Bebop to Hip-Hop (Berkeley: University of California Press, 2003), 47-51.
} 
Around the same time, the media-primarily record companies, because most radio stations refused to program black musicians ${ }^{55}$ - played a major role in defining what was black and white in terms of sound and eventually influenced the use and performance context for fiddling. Through stories and depictions presented by those who controlled the media, the cultural meanings and practices associated with rural-based fiddle music performed by whites at square dances in the South were distinct from urban-based blues and jazz performed by blacks at nightclubs in the North, Midwest, and West. Someone purchasing a "hillbilly" record expected a certain repertoire and sound (whiteness) that was distinct from what would be expected from a "race" record (blackness). Because musicians were eager to perform and become well known, most did not question the marketing used by record companies.

When record companies began recording southern country music for national audiences in the 1920s, they drew a strict color line and took black musicians out of the emerging mainstream of commercial country music. "Black players and singers had their own segregated 'race music' catalogs, almost exclusively jazz, blues, and gospel. The 'hillbilly' catalog was the exclusive province for white string and fiddle band music." 56 Exceptions include the Memphis and Louisville jug bands, the Mississippi Sheiks, and the Tennessee Chocolate Drops-groups that all incorporated fiddlers. Because some Sheiks' recordings were so musically "colorless" (i.e., contained few elements that many researchers identify with black music in terms of melody, rhythm, repertoire, and vocal inflections), OKeh, an independent company that began issuing recordings in 1918, placed some of the Sheiks' recordings in the hillbilly instead of the race series. ${ }^{57}$ That is significant because of OKeh's role in the history and development of black commercial music. When OKeh's recording of African American blues singer Mamie Smith in 1920 became a surprise hit, it resulted in the label becoming a pioneer and leader in cultivating interracial interest in recordings that were originally targeted to the black

${ }^{55}$ Lowry, "Atlanta Black Sound," 105.

${ }^{56}$ Marty Pahls, liner notes to Louie Bluie, Arhoolie 1095, 1985. Pahls's liner notes are for the soundtrack recording of Louie Bluie, a documentary film featuring African American fiddler Howard Armstrong (1909-2003). During his career, Armstrong performed and recorded with a number of string bands known by different names_e.g., Four Keys; Louie Bluie; Martin, Bogan and Armstrong; Tennessee Chocolate Drops, and Tennessee Trio. Therefore, it is noteworthy that the name Tennessee Chocolate Drops was chosen by a record company; see Erin Kelly and Alva Noe, "An Interview with 'Louie Bluie' W. Howard Armstrong,” Blues Review Quarterly 7 (Winter 1993): 33. Although Armstrong's professional career playing fiddle and other string instruments started during the early twentieth century, his popularity, like that of Joe Thompson, soared during the late twentieth century with music researchers' growing interest in role of blacks in the history of old time and country music; Howard Armstrong, personal interview with the author, Detroit, MI, 5 November 1987. Also see Wald, Escaping the Delta, 53-54.

${ }^{57}$ Some ensembles that included black and white performers (e.g., Taylor's Kentucky Boys, with black fiddler Jim Booker, and Georgia Yellow Hammers, with black fiddler Andrew Baxter) also recorded on the hillbilly series during the 1920s and 30s. Thus the Mississippi Sheiks was one of several string bands marketed to white consumers during the early twentieth century. Also see Patrick Huber, "Black Hillbillies: African American Musicians on Old-Time Records, 1924-1932," in Hidden in the Mix: The African American Presence in Country Music, ed. Diane Pecknold (Durham, NC: Duke University Press, 2013), 19-81; and Tony Thomas, "Why African Americans Put the Banjo Down," in Hidden in the Mix, 149. 
community. ${ }^{58}$ To increase sales, OKeh used advertisements in black newspapers in cities such as Chicago, Atlanta, and New York where large communities of African Americans resided. On the other hand, it was not until the mid-1920s that the media took an interest in music from rural areas, and then the focus was on ruralbased white performers. ${ }^{59}$ For example, when the Tennessee Chocolate Drops, which included fiddler Howard Armstrong and his musical partners (Carl Martin, Roland Martin, and Ted Bogan), made recordings during the 1930s, sometimes they decided to do so under different names to attract a wider more ethnically diverse audience. In his book Red River Blues, music researcher Bruce Bastin explains: "In Knoxville on April 3, 1930, Armstrong and the Martins recorded for Vocalion as the Tennessee Chocolate Drops. Their instrumentals, 'Knox County Stomp' and 'Vine Street Drag,' were reissued in the white 5000 series, more discretely credited to the Tennessee Trio. The original name was the band's idea, not the record company's." 60

African American violinists who performed jazz in the early twentieth century suffered similar fates as black old time fiddlers. ${ }^{61}$ The violin was seldom featured as the lead instrument of a jazz band, but some black violinists were used as side or accompanying musicians for female blues singers and early groups that played jazz. ${ }^{62}$ Only a few black jazz violinists (e.g., Charles Elgar and Armand Piron) made recordings as featured artists on the race series, and those who did had low record sales, possibly because the record buying public associated jazz

\footnotetext{
${ }^{58}$ Although the record companies' race and hillbilly series were created to target specific communities, cross-pollination ensued because black and white listeners enjoyed both. What was represented as white (i.e., hillbilly) by the media was supported by southern rural blacks and whites, and urban whites also appreciated recordings targeting urban blacks. Just as urban blacks supported Mamie Smith and other African American artists by purchasing their records and attending live performances, so did some urban whites. See Leonard Bowles, personal interview with the author, 25 August 1987; Christopher Lornell, personal interview with the author, 24 August 1987; Michael B. Bakan, "Way Out West on Central: Jazz in the African-American Community of Los Angeles before 1930," in California Soul: Music of African Americans in the West, ed. Jacqueline Cogdell DjeDje and Eddie S. Meadows (Berkeley: University of California Press, 1998), 56, 62; Miller, Segregating Sound, 187-240.

${ }^{59}$ Christopher Lornell, "North Carolina Pre-Blues Banjo and Fiddle," Living Blues 18 (Autumn 1974): 25-27; Lornell, Virginia's Blues, Country, and Gospel Records, 1902-1943: An Annotated Discography (Lexington: University Press of Kentucky, 1989); Lowry, "Atlanta Black Sound"; Ross Laird and Brian Rust, Discography of OKeh Records, 1918-1934 (Westport, CT: Praeger Publishers, 2004); Christopher Waterman, "Race Music: Bo Chatmon, 'Corrine Corrina,' and the Excluded Middle," in Music and the Racial Imagination, ed. Ronald Radano and Philip V. Bohlman (Chicago: University of Chicago Press, 2000), 167-205.

${ }^{60}$ Bastin, Red River Blues, 302. This statement suggests that although record executives initially created the name Tennessee Chocolate Drops, members of the group decided to use two distinct names (Tennessee Chocolate Drops and Tennessee Trio) to attract different listeners for their 1930 recordings.

${ }^{61}$ With regard to the role of the violin in genres such as jazz and art (i.e., "classical" or concert) music, cultural meanings and associations vary. Due to lack of space and my primary interest in rural-based secular forms, these genres receive limited discussion in this article.

${ }^{62}$ Probably because Mamie Smith's hit, "Crazy Blues," included a violinist among the musicians in the band, Bessie Smith and other blues singers also, on occasion, recorded with a violin in their groups. Oftentimes, the violinist was black but sometimes white violinists who were members of the record companies' studio bands accompanied blues singers. During the early 1900s, violinists were prominent in James Reese Europe's Clef Club Orchestra, and violinist Eddie South performed as a side musician in syncopated dance orchestras. See Dixon, Godrich, and Rye, Blues Gospel and Records; Southern, Music of Black Americans, 1997, 292-94, 351.
} 
with brass, woodwind, piano, and percussion-instrumentation that had been prominently used by musicians and recorded by record companies since jazz's beginnings. With minimal exposure and a sound that was distinct from brass instruments, record buyers probably had little interest in jazz that included the violin. In fact, some researchers have criticized early-twentieth-century black jazz violinists for producing "music sounds without the power and the passion of the blues." 63

Black violinists who formally trained in European art music and established careers performing and/or composing in this tradition-e.g., Edmond Dédé (18271903), Joseph Douglass (1871-1935), Clarence Cameron White (1880-1960), and Will Marion Cook (1869-1944) - have not been excluded from the African American musical canon to the same degree as fiddlers and violinists discussed heretofore. ${ }^{64}$ Yet when it was performed on or used by these artists, did listeners during the early twentieth century associate the instrument with blackness or whiteness, and what is the situation today? Because we in the United States continue to have misconceptions about the role of the fiddle/violin in African American culture, it may be difficult to give a clear-cut answer to this question. In a recent interview in The Crisis, the official publication of the National Association for the Advancement of Colored People (NAACP), author and cultural critic Mark Anthony Neal introduced the violin as an object into the conversation to explain "legibility," a concept he defines "as simply being recognizable." Interviewer Abdul Ali writes:

$\mathrm{He}$ [Neal] uses the example ... of a Black man wearing full athletic gear, bearing the Nike logo, holding a basketball. He says that this is a recognizable image of a Black man. No questions asked. It's an image we can read. However, when a Black violin player replaces the basketball player, a cognitive dissonance takes place. We're suddenly curious about this Black figure holding a violin.

"That's not something that we see, that's not something that's legible to us, we don't understand that, that's confusing to us and literally creates a whole set of questions that get attached to it," Neal says. "Why does he have this violin, can he actually play the violin, how can he afford this violin, did he steal the violin?" I mean we can go on and on. ${ }^{65}$

Although Neal uses the violin in a discussion of black masculinity, I believe the argument works well for demonstrating how misrepresentation affects many aspects of culture. Furthermore, it is an excellent example of Stuart Hall's two systems of representation (mental and language). Because of the stories that we have been told, distortion arises when "violin" and "black male" are juxtaposed. Therefore,

${ }^{63}$ Engelbert Wengel and Franz J. Humpert, "New Orleans Jazz Styles and Social Classes: Some Remarks Along with a New Piron-Reissue,” Doctor Jazz (October-November 1972): 5. Interestingly, Louisville-based violinist Clifford Hayes, who performed jazz with jug bands during the early decades of the twentieth century with fiddle as the lead or accompanying instrument, recorded more widely than New Orleans-based Piron. As is the case with fiddling, research on black jug band music is scant. However, Document Records has released several compilations of black jug band music that include fiddlers based in Memphis, Louisville, and Atlanta.

${ }^{64}$ Southern, Music of Black Americans.

${ }^{65}$ Abdul Ali, "Crisis Interview: Mark Anthony Neal," The Crisis 120, no. 4 (Fall 2013): 24, 26. 
the questions I raised for the slave era will inform the discussion of fiddling in the early twentieth century.

a. Why did blacks, whites, and record companies in the early decades of the twentieth century not want to identify fiddling with African Americans?

Not only did unintentional factors contribute to the misrepresentation of the fiddle, a number of groups, entities, and culprits were involved, and I believe their actions were intentional. In addition to the fiddle's association with whiteness during the early twentieth century, many in the United States identified the instrument with "hillbillies" and rural life, the antithesis of characteristics associated with the city. ${ }^{66}$ In 1870, roughly 25 percent of the total U.S. population lived in urban areas. By 1916, the figure had reached almost 50 percent. Due to the city's pull on peoples of all races and ethnicities during the early twentieth century, urban life became a topic of interest for researchers curious about changes that would result from urbanization. ${ }^{67}$ When scholars analyzed life in U.S. cities in the early twentieth century, discourse was framed in terms of binaries with a pro-rural and anti-urban bias. The idealized, romanticized picture of rural, agrarian life, "when people were happy, genuine, and spontaneous, ... was destroyed by the city, which is unnatural, artificial, and inherently evil." This theme reoccurred in scholarly writings and views of many U.S. residents of the time. ${ }^{68}$ For this reason, attitudes and values about rural and urban as well as the experiences of groups in these different locations belong in discussions of objects such as the fiddle because of its strong association with both historical era (pre-1900s) and place (country). Therefore, if we return to the question of why blacks, whites, and record companies during the early decades of the twentieth century did not want to identify African Americans with fiddling, we need to examine each group separately. ${ }^{69}$

Because of the black migration of the first half of the twentieth century, the views of black city dwellers carry significant weight in answering this question. For urban blacks: (1) fiddling signified the old, country life and backwardness, features

\footnotetext{
${ }^{66}$ Perceptions about the city and city life have changed over time. Anthropologists Edwin Eames and Judith Granich Goode indicate that the city "was not viewed as negatively in other times and places as it was in present-day Western industrial societies. During the Middle Ages, cities were associated with choice and freedom. ... During the Enlightenment, cities were centers of culture and knowledge. However, the coalescence of industrialization and urban growth during the Industrial Revolution led to the view of urban life as dehumanizing." Edwin Eames and Judith Granich Goode, Anthropology of the City: An Introduction to Urban Anthropology (Englewood Cliffs, NJ: Prentice-Hall, 1977), 55. For a discussion of the country music industry's efforts to turn "away from twangy steel guitars and fiddles of earlier styles," see Jeremy Hill, "'Country Comes to Town': Country Music Construction of a New Urban Identity in the 1960s," Popular Music and Society 34, no. 3 (July 2011): 294.

${ }^{67}$ For whites, the move from rural to urban areas occurred much earlier than other ethnic groups in the United States. U.S. census data indicate that by 1920 , roughly 51 percent of the white population lived in cities compared to 34 percent of blacks; the black population's shift from predominantly rural to overwhelmingly urban occurred over several decades: 1930 (44 percent urban), 1940 (49 percent urban), 1950 (62 percent urban), and 1960 (73 percent urban).

${ }^{68}$ Eames and Goode, Anthropology of the City, 54; Franklin, From Slavery to Freedom, 311

${ }^{69}$ The following analysis is based on my readings in U.S. history and culture, field research in rural and urban areas of the United States, and interviews with both black and white fiddlers and researchers.
} 
contrary to the new, modern, and progressive lifestyle African Americans were attempting to create in cities outside the South. (2) The fiddle symbolized racism and negative images that urban blacks were still experiencing in spite of their move to urban communities. Thus, blacks did not need the fiddle to remind them of their precarious position. ${ }^{70}$

On the whole, some whites nationwide did not recognize the fiddle as a black tradition for other reasons: (1) The fiddle represented southern white rural culture and country life, not urbanity. Thus, whites' romanticized perceptions of the rural South were in keeping with those described by social scientists. (2) Not only did blacks (in the cultural memory of many whites) fail to represent the ideals associated with fiddling (rural, wholesome, family life), but also the place (urban areas throughout the United States) where both whites and blacks lived did not offer images or representations associated with fiddling. Commenting on the musical tastes of some whites during the 1920s and 1930s, music historian Elijah Wald writes, "Many white Southerners had a fond attachment to the good old days 'before the war,' and the nostalgic advertising rubrics were designed to appeal to such feelings. This appeal would remain a commonplace of country-and-western music."71

Record companies did not make recordings of black fiddlers because, as commercial entities, they were interested in profit. Their marketing was based on perceived attitudes within the larger populace, which suggested that: (1) Fiddling was not appealing to blacks living in cities who had the means to buy records. Although black fiddlers were readily available to make recordings (and some did), record company executives also knew that whites would not buy fiddle recordings made by blacks. When record companies made recordings of black fiddlers, they marketed them on the hillbilly label because the market existed in rural areas. (2) Southern blacks who may have been interested in listening to black fiddling did not always have the income to purchase recordings, while others could freely hear fiddling at frolics and square dances in their local communities. So record company executives probably did not believe it was necessary to serve this market.

b. What are the repercussions?

Misrepresenting the fiddle as a white, rural instrument has had an impact on many facets of cultural life in the United States, so much so that the repercussions are too complex to discuss in great detail in this essay. Because of the difficulty in fully addressing this question, my comments will be limited to three areas: how misrepresentation (1) affected the musical preferences and tastes of black musicians,

\footnotetext{
${ }^{70}$ Although the fiddle/violin is not discussed, "Jelly Roll” Morton's comments about the New Orleans musicians he invited to perform with him in Los Angeles provides one example of how urban transplanted artists regarded musicians from the South: "We knew they would arrive [in Los Angeles] in the antiquated dress habitual to New Orleans musicians. ... We were afraid somebody would see them and think they were clowns, so we rushed them to the tailors and put them in some decent-looking clothes." Alan Lomax, Mister Jelly Roll: The Fortunes of Jelly Roll Morton (New York: Grosset and Dunlap, 1950), 163. Also see Bakan, "Way Out West on Central," 37-38; and Thomas, "Why Did African Americans Put the Banjo Down," 144, 164-65.

${ }^{71}$ Wald, Escaping the Delta, 31, 52; Hill, “Country Comes to Town," 294.
} 
(2) promoted the notion of difference to such a degree that shared features were dismissed or ignored, and (3) contributed to misconceptions that continue to exist in many writings about what we now call U.S. (or American) music. Because early media forms (radio and records) played a significant role in the cultural meanings and practices that exist, much of the following focuses on their impact.

First, what appeared in the media shaped musical tastes. When blacks did not hear themselves playing the fiddle on recordings or the radio, many turned to other instruments (i.e., guitar) and musical genres (blues and jazz instead of old time and country). Commenting on how misrepresentation by the media affected some black musicians, ethnomusicologist Christopher Waterman writes: "Interviews with blues performers who recorded in the 1920s and 1930s suggest that gatekeepers such as producers and recording engineers frequently urged performers to narrow their repertoires in the interest of producing a saleable product. In the late 1920s, when fiddle-led bands were a mainstay of the hillbilly music business, African-American string bands were sometimes turned away from recording sessions. ${ }^{72}$ Some black popular musicians, like New Orleans-born Lonnie Johnson, stopped playing the fiddle and concentrated on guitar. When Tom Dumas, a black fiddler from the east hills of Mississippi where he had "played country tunes on his fiddle for black square dances" most of his life, moved west to the Mississippi Delta, he was surprised that "blacks had no interest in his music. They considered his fiddle tunes 'white folks' music' and as a result he gave up the music which four generations of his family had played." $" 3$

Just as minstrel performers misrepresented black music and performers by creating an "imagined" tradition based on distortions and negative stereotypes of black musicking, the same occurred with recorded sound. The ads and marketing strategies used to promote recordings greatly influenced who would buy a particular product. So when the buying public did not see or hear what they had been programmed to associate with a particular ethnic or cultural group, they were not interested. Gerald Milnes, author of Play of a Fiddle: Traditional Music, Dance, and Folklore in West Virginia, explains how misrepresentation affected the development of both African and European American music:

\begin{abstract}
Having established racial categories, the companies eventually geared their promotional efforts to the white market. Whereas promotional materials for old-time music recordings pictured responsible-looking whites playing, dancing, and being jolly in more dignified settings, throughout the latter half of the nineteenth-century materials depicting African American musicians were caricatured stereotypes. Watermelon patches and lazy African Americans lounging about, sometimes with banjos and in humorous situations, were often shown. ... This may have instigated the beginning of the end for African American oldtime string music. The one-two punch of derisive media and the promotion of race records took effect. Blues was the musical expression of blacks, and old-time music became an expression of whites. $^{74}$
\end{abstract}

\footnotetext{
${ }^{72}$ Waterman, "Race Music," 180; also see Miller, Segregating Sound, 4

${ }^{73}$ William Ferris, Blues from the Delta (Garden City, NY: Anchor Books, 1979), 96-97. Also see Miller, Segregating Sound, 4.

${ }^{74}$ Gerald Milnes, Play of a Fiddle: Traditional Music, Dance, and Folklore in West Virginia (Lexington: University Press of Kentucky, 1999), 106
} 
Second, acknowledging fiddling as a black tradition comparable to that created by whites would have challenged and undermined the notion of difference within the United States. The cultural meanings and practices on the issue of difference had been set in the memory of blacks and whites during slavery. Like performers and producers of blackface minstrelsy, those who were in control of the media or had access to its resources did not desire to change the status quo because misrepresentation and perpetuating stereotypes made too much profit. Presenting the reality of what existed would have negatively affected a significant segment of the market. As Karl Hagstrom Miller explains, "By targeting specific groups with their own unique music, companies could draw the attention of untapped consumers to the wonders of the talking machine just as they had done in their international campaigns."75

Placing emphasis on synergy would have led to a more inclusive discussion about black and white contributions to musicking in the United States. The fact that African cultural memory, interaction between the races, and shared performance practices helped to make fiddling in certain parts of the United States, particularly the South, distinct from that in other parts of the world is sometimes noted in scholarly writings but rarely emphasized. In fact, sharing was an essential component of African peoples before their arrival in the Americas. "Prior to contact with Europeans, ethnic groups in Africa regularly interacted with each other through trade, migration, and warfare, which resulted in the borrowing and integration of new traditions into their own. Therefore, it was common for them to create syncretic musical forms and use similar instruments in variant ways. Upon arrival in the New World, Africans used different strategies to survive. Although many maintained African practices, others selectively fused musical features from contrasting parts of Africa and Europe." ${ }^{76}$ In the Americas, enslaved Africans had to establish a variety of cultural practices and meanings so they could adapt to whatever situation they found themselves in. ${ }^{77}$ In times of oppression, one could use practices to resist or protest; in times of joy, they could be used to celebrate, honor, or pay tribute. When at a crossroad, cultural practices were essential in negotiating a resolution. Whereas whites often used difference to control, for many blacks it instead became a strategy for survival.

When black fiddlers learned the repertoire and performance techniques of Europeans to satisfy the tastes of whites, they fused these elements with African practices to create a performance style that helped distinguish fiddling in the Upper South (Virginia, West Virginia, North Carolina) from that in other parts of the United States and world cultures. ${ }^{78}$ Folklorist and fiddler Alan Jabbour argues that

${ }^{75}$ Miller, Segregating Sound, 189.

${ }^{76}$ DjeDje, “African American Music to 1900," 134.

77 Solomon Northup was a nineteenth-century free black fiddler sold into slavery who used his talents and status as a slave fiddler to not only survive but also regain his freedom. See Solomon Northup, Twelve Years a Slave: Narrative of Solomon Northup, a Citizen of New-York, Kidnapped in Washington City in 1841, and Rescued in 1853 (Baton Rouge: Louisiana State University Press, [1853] 1968); also see Twelve Years a Slave, a film directed by Steve McQueen, 2013.

${ }^{78}$ See J. H. Kwabena Nketia, "African Roots of Music in the Americas: An African View," Jamaica Journal 43 (March 1979): 12-17; Brown, “The African/African American Idiom in Music,” 115-34. 
influences from African American culture account for the use of syncopation (i.e., off-beat phrasing) in the bowing styles of both black and white fiddlers in the Upper South. He also believes that this type of bowing began during the late eighteenth and early nineteenth centuries and not in the early twentieth century with the advent of radio and recordings. Furthermore, both white and black musicians attribute the use of slurs, slides, and glides in U.S. fiddle music to black culture. ${ }^{79}$

Finally, due to misrepresentation, the history of both black and white music cultures in the United States contains errors and omissions that need to be reconsidered. At present, for example, our knowledge of twentieth-century African American music is based primarily on traditions developed in urban areas, thereby inferring that all blacks were urban born and urban dwellers. Although large numbers of blacks moved and settled in urban areas, many did not leave the South or rural areas where their ancestors were born, and the U.S. black population did not become predominantly urban until the late 1940s. So what do we know about the music of those who did not migrate? Did they maintain the traditions of their ancestors? Did they create new genres or performance styles? To what extent were they influenced by activities in the city? What role did they play in the development of what is now called African American music?

In conclusion, misrepresenting (i.e., deceiving intentionally or unintentionally) the role of blacks in the development of fiddling in the United States has distorted our understanding of the history and development of both African and European American music in several areas. First, the omission has skewed our knowledge of connections with both Africa and Europe; similar performance practices may have existed and performed by musicians in both areas prior to contact. Second, misrepresentation dismisses the sharing and fusion of concepts, ideas, and performance techniques between blacks and whites, which began in the seventeenth century and continues to present day in a variety of forms. Third, the omission perpetuates stereotypes and misconceptions about black music. Do we really understand the totality or have a holistic view of the different musics African Americans have created and performed, how (and in what contexts) they created the music, and why it was performed? As Stuart Hall states, "it is participants in a culture who give meaning to people, objects, and events." ${ }^{\text {" To }}$ Therefore, until we provide a more accurate representation of our cultural products, by critically examining and analyzing who benefits when misrepresentation is framed and marketed in a certain manner, we will never move forward in our research and teaching. More importantly, we need to be more cognizant of traditions that have been marginalized or placed on the periphery of a music culture. As this article demonstrates, research

${ }^{79}$ Alan Jabbour, "Fiddle Tunes of the Old Frontier: In Search of a Better Historical Model," unpublished manuscript, 1985; Jabbour, "Fiddle Music," in American Folklore: An Encyclopedia, ed. Jan Harold Brunvand (New York: Garland, 1996), 253-56; Wells, "Fiddling as an Avenue," 144; Harrod, personal interview. During the 1980s, John Harrod performed regularly with Bill Livers, a black fiddler who lived in Owenton, Kentucky; Bill Livers, personal interview with the author, Owenton, KY, 6 August 1987. In 1997, Harrod and others produced a recording that included music by Livers; see Guthrie T. Meade, John Harrod, and Mark Wilson, Traditional Fiddle Music of Kentucky, vol. 2: Along the Kentucky River, Rounder CD 0377, 1997.

${ }^{80}$ Hall, "Introduction," 10. 
on black fiddling offers an avenue into successful investigation of broader issues such as culture contact, race, the media, and (mis)representation. In the future, these topics and issues should be considered when investigating African American music generally and specifically the development of black fiddling.

\section{References}

\section{Books and Articles}

Adams, Greg C. "Nineteenth-Century Banjos in the Twenty-First Century: Custom and Tradition in a Modern Early Banjo Revival." M.A. thesis, University of Maryland, College Park, 2012.

Adams, Greg C., and Shlomo Pestcoe. "The Jola Akonting: Reconnecting the Banjo to its West African Roots.” Sing Out! 51, no. 1 (2007): 43-51.

Adams, Greg C., and Paul Sedgwick. "Encountering the Akonting: A Cultural Exchange." The Old-Time Herald: A Magazine Dedicated to Old-Time Music 10, no. 9 (February-March 2007): 36-41.

Ali, Abdul. “Crisis Interview: Mark Anthony Neal.” The Crisis 120, no. 4 (Fall 2013): 24-28.

Bakan, Michael B. "Way Out West on Central: Jazz in the African-American Community of Los Angeles before 1930." In California Soul: Music of African Americans in the West, ed. Jacqueline Cogdell DjeDje and Eddie S. Meadows, 23-78. Berkeley: University of California Press, 1998.

Bastin, Bruce. Red River Blues: The Blues Tradition in the Southeast. Urbana: University of Illinois Press, 1986.

Brown, Ernest D. "The African/African American Idiom in Music: Family Resemblances in Black Music.” In African Musicology: Current Trends, Vol. 2, ed. Jacqueline Cogdell DjeDje, 115-34. Los Angeles and Atlanta: UCLA International Studies and Overseas Program/The James S. Coleman African Studies Center and African Studies Association Press, 1992.

Conway, Cecelia. African Banjo Echoes in Appalachia: A Study of Folk Traditions. Knoxville: University of Tennessee Press, 1995.

Courlander, Harold. Negro Folk Music, U.S.A. New York: Columbia University Press, 1963.

Curtin, Philip. The Atlantic Slave Trade: A Census. Madison: University of Wisconsin Press, 1969.

de Barros, Philip. "How Far Inland Did the Arm of the Slave Trade Reach? An Overview of the Slave Trade in Togo." Excavating the Past: Archaeological Perspectives on Black Atlantic Regional Networks, Conference in Honor of UCLA Emeritus Professor Merrick Posnansky. Unpublished manuscript, 3-4 April 2009, 1-46. http://www2.palomar.edu/users/pdebarros/TOGO\%20PAPER \%20with\%20MAPS\%20(5).pdf.

Diouf, Sylviane A. Servants of Allah: African Muslims Enslaved in the Americas. New York: New York University Press, 1998.

Dixon, Robert M. W., John Godrich, and Howard W. Rye, eds. Blues and Gospel Records: 1890-1943, 4th ed. New York: Oxford University Press, 1997. 
DjeDje, Jacqueline Cogdell. Distribution of the One String Fiddle in West Africa. Los Angeles: UCLA Program in Ethnomusicology, Department of Music, 1980.

- "West Africa: An Introduction." In The Garland Encyclopedia of World Music. Vol. 1, Africa, ed. Ruth, M. Stone, 442-70. New York: Garland, 1998.

_. "African American Music to 1900." In The Cambridge History of American Music, ed. David Nicholls, 103-34. Cambridge: Cambridge University Press, 1998.

- Fiddling in West Africa: Touching the Spirit in Fulbe, Hausa, and Dagbamba Cultures. Bloomington: Indiana University Press, 2008.

- Fiddling in West Africa (1950s-1990s): The Songbook. Los Angeles: UCLA Ethnomusicology Publications, 2008.

Eames, Edwin, and Judith Granich Goode. Anthropology of the City: An Introduction to Urban Anthropology. Englewood Cliffs, NJ: Prentice-Hall, 1977.

Eltis, David. "The Volume and Structure of the Transatlantic Slave Trade: A Reassessment." In "New Perspectives on the Transatlantic Slave Trade.” The William and Mary Quarterly 3rd ser., 58, no. 1 (January 2001): 17-46.

Epstein, Dena. “The Folk Banjo: A Documentary History.” Ethnomusicology 19, no. 3 (September 1975): 347-71.

- Sinful Tunes and Spirituals: Black Folk Music to the Civil War. Urbana: University of Illinois Press, 1977.

Evans, David. Liner notes to Let's Get Loose: Folk and Popular Blues Styles from the Beginnings to the Early 1940s. New World Records NW 290, 1978.

Ferris, William. Blues from the Delta, Garden City, NY: Anchor Books, 1979.

Franklin, John Hope. From Slavery to Freedom: A History of Negro Americans. 5th ed. New York: Alfred A. Knopf [1947], 1980.

Gilman, Caroline Howard. Recollections of a Southern Matron. New York: Harper and Brothers, 1838.

Goertzen, Christopher. "English and Scottish Music.” In The Garland Encyclopedia of World Music. Vol. 3, The United States and Canada, ed. Ellen Koskoff, 831-41. New York: Garland, 2001.

Hall, Stuart. "Introduction.” In Representation: Cultural Representations and Signifying Practices, ed. Stuart Hall, 1-11. London: Open University/Sage, 1997.

—. "Representation, Meaning and Language." In Representation: Cultural Representations and Signifying Practices, ed. Stuart Hall, 15-74. London: Open University/Sage, 1997.

Hill, Jeremy. "'Country Comes to Town': Country's Music's Construction of a New Urban Identity in the 1960s." Popular Music and Society 34 (July 2011): 293-308.

Holloway, Joseph E. “The Origins of African American Culture.” In Africanisms in American Culture, 2nd ed., ed. Joseph E. Holloway, 18-38. Bloomington: Indiana University Press, 2005.

Huber, Patrick. "Black Hillbillies: African American Musicians on Old-Time Records, 1924-1932." In Hidden in the Mix: The African American Presence in Country Music, ed. Diane Pecknold, 19-81. Durham, NC: Duke University Press, 2013.

Jabbour, Alan. "Fiddle Tunes of the Old Frontier: In Search of a Better Historical Model." Unpublished manuscript, 1985. 
"Fiddle Music." In American Folklore: An Encyclopedia, ed. Jan Harold Brunvand, 253-56. New York: Garland, 1996.

Jackson, Irene V. Afro-American Religious Music: A Bibliography and a Catalogue of Gospel Music. Westport, CT: Greenwood, 1979.

Jägfors, Ulf. "The African Akonting and the Origin of the Banjo." The Old-Time Herald: A Magazine Dedicated to Old-Time Music 9, no. 2 (Winter 2003-4): 26-33.

Jenoure, Theresa. "The Afro-American Fiddler." Contributions in Black Studies: A Journal of African and Afro-American Studies 5, no. 2 (1981): 68-81.

Kelly, Erin, and Alva Noe. "An Interview with 'Louie Bluie' W. Howard Armstrong." Blues Review Quarterly 7 (Winter 1993): 26-33.

Laird, Ross, and Brian Rust. Discography of OKeh Records, 1918-1934. Westport, CT: Praeger, an imprint of Greenwood Publishing Group, Inc., 2004.

Lomax, Alan. Mister Jelly Roll: The Fortunes of Jelly Roll Morton, New Orleans Creole and "Inventor of Jazz." New York: Grosset and Dunlap, 1950.

Lornell, Christopher (Kip). "North Carolina Pre-Blues Banjo and Fiddle." Living Blues 18 (Autumn 1974): 25-27.

- Virginia's Blues, Country, and Gospel Records, 1902-1943: An Annotated Discography. Lexington, KY: University Press of Kentucky, 1989.

Lott, Eric. Love and Theft: Blackface Minstrelsy and the American Working Class. New York: Oxford University Press, 1993.

Lowry, Pete. "Atlanta Black Sound: A Survey of Black Music from Atlanta During the Twentieth Century." Atlanta Historical Society Bulletin 21, no. 2 (Summer 1977): 88-113.

Marcuse, Sibyl. Musical Instruments: A Comprehensive Dictionary. New York: W. W. Norton, 1975.

Marshall, Howard Wight, Vivian Williams, and Phil Williams. Now That's a Good Tune: Masters of Traditional Missouri Fiddling, rev. ed. Seattle, WA: Voyager Recordings and Publications, 2008.

Maultsby, Portia K. "The Translated African Cultural and Music Past." In African American Music: An Introduction, 2nd ed., ed. Mellonee V. Burnim and Portia K. Maultsby, 3-22. New York: Routledge, 2015.

Miller, Karl Hagstrom. Segregating Sound: Inventing Folk and Pop Music in the Age of Jim Crow. Durham, NC: Duke University Press, 2010.

Milnes, Gerald. Play of a Fiddle: Traditional Music, Dance, and Folklore in West Virginia. Lexington, KY: University Press of Kentucky, 1999.

Nketia, J. H. Kwabena. "African Roots of Music in the Americas: An African View." Jamaica Journal 43 (March 1979): 12-17.

Northup, Solomon. Twelve Years a Slave: Narrative of Solomon Northup, a Citizen of New-York, Kidnapped in Washington City in 1841, and Rescued in 1853, ed. Sue Eakin and Joseph Logsdon. Baton Rouge: Louisiana State University Press, [1853] 1968.

Odum, Howard W. "Folk-Song and Folk-Poetry as Found in the Secular Songs of the Southern Negroes." Journal of American Folklore 24, no. 93 (July-September 1911): 255-94; and 24, no. 94 (October-December 1911): 351-96. 
Oliver, Paul. Savannah Syncopators: African Retentions in the Blues. New York: Stein and Day, 1970.

. The Story of the Blues. Middlesex, England: Penguin Books, [1969)] 1972.

Pahls, Marty. Liner notes to Louie Bluie. Arhoolie LP 1095, 1985.

Palmer, Colin A. "From Africa to the Americas: Ethnicity in Early Communities of the Americas." Journal of World History 6, no. 2 (Fall 1995): 223-36.

Perbi, Akosua Adoma. A History of Indigenous Slavery in Ghana from the 15th to the 19th Century. Legon-Accra, Ghana: Sub-Saharan Publishers, 2004.

Pestcoe, Shlomo, and Greg Adams. "Banjo Roots Research: Changing Perspectives on the Banjo's African American Origins and West African Heritage." In Banjo Roots and Branches: New Explorations, ed. Robert Winans. Urbana: University of Illinois Press, forthcoming.

Price, Tanya Y. "Rhythms of Culture: Djembe and African Memory in AfricanAmerican Cultural Traditions." Black Music Research Journal 33, no. 2 (Fall 2013): 227-47.

Radano, Ronald. "Race, Ethnicity, and Nationhood." In The Garland Encyclopedia of World Music. Vol. 3, The United States and Canada, ed. Ellen Koskoff, 63-72, 74-75. New York: Garland, 2001.

Ramsey, Guthrie P., Jr. Race Music: Black Cultures from Bebop to Hip-Hop. Berkeley: University of California Press, 2003.

Roberts, John Storm. Black Music of Two Worlds: African, Caribbean, Latin, and African-American Traditions, 2nd ed. New York: Schirmer Books, [1972] 1998.

Roediger, David R. The Wages of Whiteness: Race and the Making of the American Working Class. New York: Verso Books, 1991.

Russell, Tony. Blacks, Whites and Blues. New York: Stein and Day, 1970.

Small, Christopher. Musicking: The Meanings of Performing and Listening. Middletown, CT: Wesleyan University Press, 1998.

Smith, Dale. "Missouri's Finest Fiddlers: Howard Marshall Traces Missouri's Fiddling History." Mizzou: The Magazine of Mizzou Alumni Association, University of Missouri (Summer 2009). http://mizzoumagarchives.missouri.edu/ 2009-summer/features/fiddle/index.php.

Smith, Mark M. "Remembering Mary, Shaping Revolt: Reconsidering the Stono Rebellion.” Journal of Southern History 67, no. 3 (August 2001): 513-34.

Southern, Eileen. The Music of Black Americans: A History. New York: W. W. Norton, 1971.

- The Music of Black Americans: A History, 2nd ed. New York: W. W. Norton, 1983.

- The Music of Black Americans: A History, 3rd ed. New York: W. W. Norton, 1997.

Szego, Peter. "Searching for the Roots of the Banjo-Part I." The Old-Time Herald: A Magazine Dedicated to Old-Time Music 10, no. 4 (April-May 2006): 14-23.

—. "Searching for the Roots of the Banjo-Part II." The Old-Time Herald: A Magazine Dedicated to Old-Time Music 10, no. 5 (June-July 2006): 10-20.

Talley, Thomas Washington. Negro Folk Rhymes (Wise and Otherwise). New York: Macmillan, 1922. 
Taylor, Yuval, and Jake Austen. Darkest America: Black Minstrelsy from Slavery to Hip-Hop. New York: W. W. Norton, 2012.

Thomas, Tony. "Why Black Banjo? The Black Banjo List Serve and the Black Banjo Gathering." The Old-Time Herald: A Magazine Dedicated to Old-Time Music 9, no. 7 (Spring 2005): 44-45.

. "Why African Americans Put the Banjo Down." In Hidden in the Mix: The African American Presence in Country Music, ed. Diane Pecknold, 143-70. Durham, NC: Duke University Press, 2013.

Wald, Elijah. Escaping the Delta: Robert Johnson and the Invention of the Blues. New York: HarperCollins, 2004.

Walsh, Lorena S. "The Transatlantic Slave Trade and Colonial Chesapeake Slavery." Organization of American Historians Magazine of History 17, no. 3 (April 2003): 11-15.

Waterman, Christopher. 'Race Music: Bo Chatmon, 'Corrine Corrina,' and the Excluded Middle." In Music and the Racial Imagination, ed. Ronald Radano and Philip V. Bohlman, 167-205. Chicago: University of Chicago Press, 2000.

Wax, Darold D. “'A People of Beastly Living': Europe, Africa and the Atlantic Slave Trade." Phylon: The Atlanta University Review of Race and Culture 41, no. 1 (1980): 12-24.

Webster's New Collegiate Dictionary. Henry Bosley Woolf, ed. Springfield, MA: Merriam, 1974.

Wells, Paul F. "Fiddling as an Avenue of Black-White Musical Interchange." Black Music Research Journal 23, nos. 1-2 (Spring/Fall 2003): 135-47.

Wengel, Engelbert, and Franz J. Humpert. "New Orleans Jazz Styles and Social Classes: Some Remarks Along with a New Piron-Reissue.” Doctor Jazz (OctoberNovember 1972): 5-8.

Wilson, Olly. "The Significance of the Relationship between Afro-American Music and West African Music." The Black Perspective in Music 2, no. 1 (Spring 1974): 3-22.

Wilson, Sule Greg. Review of African Banjo Echoes in Appalachia: A Study in Folk Tradition by Cecelia Conway. University of Tennessee Press, 1995. Banjo Newsletter 23, no. 1 (August 1996): 7-10.

Winans, Robert B. "Black Banjo Tradition in Virginia and West Virginia." Folklore and Folklife in Virginia: Journal of the Virginia Folklore Society 1 (1979): 7-30.

_. "Black Instrumental Music Traditions in the Ex-Slave Narratives." Black Music Research Journal 10, no. 1 ([Spring 1982] Spring 1990): 43-53.

_. "Black Musicians in Eighteenth-Century America: Evidence from Runaway Slave Advertisements." In Banjo Roots and Branches: New Explorations, ed. Robert B. Winans. Urbana: University of Illinois Press, forthcoming.

Wolfe, Charles. "Black String Bands: A Few Notes on a Lost Cause." The Old-Time Herald: A Magazine Dedicated to Old-Time Music 1, no. 1 (Fall 1987): 15-18.

. Review of With Fiddle and Well-Rosined Bow: Old-Time Fiddling in Alabama

by Joyce Cauthen. University of Alabama Press, 1989. Devil's Box 23, no. 2 (Summer 1989): 48-50.

. The Devil's Box: Masters of Southern Fiddling. Nashville, TN: Country Music Foundation Press and Vanderbilt University Press, 1997. 
Work, John W., Lewis Wade Jones, Samuel C. Adams Jr., Robert Gordon, and Bruce Nemerov, eds. Lost Delta Found: Rediscovering the Fisk University-Library of Congress Coahoma County Study, 1941-1942. Nashville, TN: Vanderbilt University Press, 2005.

Wyatt, Marshall. Liner notes to Violin, Sing the Blues for Me: African-American Fiddlers 1926-1949. Old Hat CD 1002, 1999.

- Liner notes to "Folks, He Sure Do Pull Some Bow!" Vintage Fiddle Music, 1927-1935. Blues, Jazz, Shuffles and Rags. Old Hat CD 1003, 2001.

\section{Interviews and Lectures}

Armstrong, Howard. Personal interview with the author, Detroit, 5 November 1987. Blake, Jr., John. "Jazz and the Violin.” Billy Taylor's Jazz at The Kennedy Center. Lecture demonstration with Billy Taylor and the Billy Taylor Trio, The John F. Kennedy Center Performing Arts Series, Washington, D.C., 7 February 2001. http://www.npr.org/programs/btaylor/archive/blake.html.

Bowles, Leonard. Personal interview with the author, Martinsville, Virginia, 25 August 1987.

Briggs, Karen. "Women in Jazz." Lecture demonstration in Ethnomu M109, University of California, Los Angeles, 11 March 2008.

Carter, Regina. Personal interview with the author, San Francisco, CA, 21 March 2011.

DeVane, Dwight. Personal interview with the author, Polk City, FL, 10 August 1987. Harrod, John. Personal interview with the author, Owenton, KY, 6 August 1987.

Livers, Bill. Personal interview with the author, Owenton, KY, 6 August 1987.

Linford, Scott. Personal email communication to the author, 27 April 2015.

Lornell, Christopher (Kip). Personal interview with the author, Ferrum, Virginia, 24 August 1987.

Thompson, Joe. Personal interview with the author, Mebane, NC, 21 August 1987.

\section{Films and Recordings}

Ain't Gonna Rain No More: Blues and Pre-Blues from Piedmont North Carolina, Kip Lornell, producer. Rounder LP 2016, 1978.

Altamont: Black Stringband Music from the Library of Congress, Bob Carlin, producer. Rounder LP 0238, 1989.

Black Banjo Songsters of North Carolina and Virginia, Cece Conway and Scott Odell, producers. Smithsonian Folkways CD 40079, 1998.

Carolina Chocolate Drops and Joe Thompson, Tim Duffy, producer. Music Maker Recordings-Lucky Guitar Music MMCD 101, 2008.

Christeson, R. P., ed. Old Time Fiddler's Repertory. Historic Field Recordings of FortyOne Traditional Tunes. Columbia: University of Missouri Press, [1976] 2011.

DjeDje, Jacqueline Cogdell, compiler. Fiddling in West Africa (1950s-1990s): The CD Recording. Los Angeles: UCLA Ethnomusicology Publications, 2007.

Eight-Hand Sets and Holy Steps: Early Dance Tunes and Songs of Praise from North Carolina's Black Tradition, Glenn Hinson, producer. Longleaf Records LL001RE, [1978] 1989. 
Joe Thompson: Family Tradition. Rounder CD 2161, 1999.

Meade, Guthrie T., John Harrod, and Mark Wilson, eds. Traditional Fiddle Music of Kentucky, Vol. 2: Along the Kentucky River. Rounder CD 0377, 1997.

Twelve Years a Slave (film), Steve McQueen, director. Regency Enterprises, River Road Entertainment, Plan B Entertainment, New Regency, and Film4 Productions, 2013.

Work III, John W. Recording Black Culture, Bruce Nemerov and Evan Hatch, producers. Spring Fed Records SFR 104, 2007. 